\title{
A reactive nitrogen budget of the Bohai Sea based on an isotope mass balance model
}

Shichao Tian ${ }^{1}$, Birgit Gaye ${ }^{1}$, Jianhui Tang ${ }^{2}$, Yongming Luo ${ }^{2,3}$, Wenguo Li ${ }^{4}$, Niko Lahajnar ${ }^{1}$, Kirstin

Dähnke $^{5}$, Tina Sanders ${ }^{5}$, Tianqi Xiong ${ }^{6}$, Weidong Zhai ${ }^{6}$, Kay-Christian Emeis ${ }^{1,5}$

${ }^{1}$ Institute for Geology, Universität Hamburg, Hamburg, 20146, Germany

${ }^{2}$ Yantai Institute of Coastal Zone Research, Chinese Academy of Sciences, Yantai, China

${ }^{3}$ Institute of Soil Science, Chinese Academy of Siences, Nanjing, China

${ }^{4}$ Institute of Oceanography, Universität Hamburg, Hamburg, 20146, Germany

${ }^{5}$ Helmholtz-Zentrum Geesthacht (HZG), Institute for Coastal Research, Geesthacht, 21502, Germany

$10{ }^{6}$ Institute of Marine Science and Technology, Shandong University, Qingdao, China

Correspondence to: Shichao Tian (shichao.tian@uni-hamburg.de) 


\begin{abstract}
The Bohai Sea is a semi-closed marginal sea impacted by one of the most populated areas of China. The supply of nutrients, markedly that of reactive nitrogen, via fluvial and atmospheric transport has strongly increased in parallel with the growing population. It is therefore crucial to quantify the reactive nitrogen input to the BHS and to understand the processes and determine the quantities of nitrogen eliminated in and exported from the BHS. The nitrogen budget and in particular the internal sources and sinks of nitrate were constrained by using a mass-based and dual stable-isotope approach based on $\delta^{15} \mathrm{~N}$ and $\delta^{18} \mathrm{O}$ of nitrate. Samples of water, suspended matter and sediments were taken in the BHS in spring (March and April) and summer (July and August) 2018. The Yellow River was sampled in May, July to November and Daliao River, Hai River, Luan
\end{abstract} River and Xiaoqing River were sampled in November of 2018. In addition to nutrient, particulate organic carbon and nitrogen concentrations, the dual isotopes of nitrate $\left(\delta^{15} \mathrm{~N}\right.$ and $\left.\delta^{18} \mathrm{O}\right), \delta^{15} \mathrm{~N}$ of suspended matters and sediments were determined. Based on the available mass fluxes and isotope data an updated nitrogen budget is proposed. Compared to previous estimates, it is more complete and includes the impact of interior cycling (nitrification) on the nitrate pool. The main nitrogen sources are rivers contributing 17.5\%-20.6\% and the combined terrestrial runoff (including submarine discharge of nitrate with fresh ground water) accounting for $22.6 \%-26.5 \%$ of the nitrate input to the BHS while atmospheric input contributes only $6.3 \%$ $7.4 \%$ to total nitrate. An unusually active interior nitrogen cycling contributes $59.1 \%-71.2 \%$ to total nitrate via nitrification. Nitrogen is mainly trapped in the BHS and mainly removed by sedimentation (96.4\%-96.9\%) and only very little is exported to the YS (only $1.7 \%-2.0 \%$ ). At present denitrification is only active in the sediments and removes $1.4 \%-1.7 \%$ of nitrate from the pool. A further eutrophication of the BHS could, however, induce water column hypoxia and denitrification as already observed - often seasonally off river mouths - in other marginal seas. 


\section{Introduction}

Reactive or fixed nitrogen $\left(\mathrm{N}_{\mathrm{r}}\right)$ is an essential nutrient of life on earth, but only few organisms can fix dinitrogen directly from the large atmospheric dinitrogen pool. Since the invention of the Haber-Bosch process the amount of fixed nitrogen (120

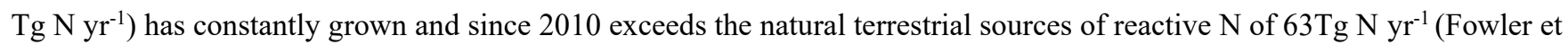
al., 2013). Hotspots of agricultural $\mathrm{N}$ fertilizer application shifted from the US and western Europe in the 1960s to eastern Asia in the early $21^{\text {st }}$ century (Lu and Tian, 2017). In China, the Haber-Bosch process produces $37.1 \mathrm{Tg} \mathrm{N} \mathrm{yr}^{-1}$, which is almost 3 times of the biological $\mathrm{N}$ fixation of $12.0 \mathrm{Tg} \mathrm{N} \mathrm{yr}^{-1}$. An estimated $32.0 \mathrm{Tg} \mathrm{N} \mathrm{yr}^{-1}$ are produced for fertilizer (Gu et al., 2015) and China accounted for $29 \%$ of the global ammonium production in 2018 (IFA, 2019). The leakage and volatilization of this man-made reactive nitrogen has strongly impacted limnic and marine ecosystems in China. Riverine reactive nitrogen discharged to the ocean from China was estimated at 5.4 $\mathrm{Tg} \mathrm{N} \mathrm{yr}^{-1}$ (Gu et al., 2015). The total load of Chinese major estuaries to coastal seas was about $9 \%$ of the global river load for DIN and $1.5 \%$ of the global phosphate load, respectively (Smith et al., 2003; Liu et al., 2009).

The Bohai Sea (BHS) is a semi-enclosed basin with a surface area of $77 \times 10^{3} \mathrm{~km}^{2}$ and an average depth of $18 \mathrm{~m}$ (Chen, 2009; $\mathrm{Su}, 2001$ ) that is heavily impacted by human activities in one of the most densely populated terrestrial catchments of the world. It exchanges salt water with the Yellow Sea (YS) through Bohai Strait and the Yellow River is a major source of freshwater to BHS (Chen, 2009). During the last fifty years, rising anthropogenic activity in the catchment induced severe environmental changes in the BHS, including increasing salinity, temperature, concentrations of dissolved inorganic nitrogen (DIN) and changes in stoichiometric nutrient ratios (Zhao et al., 2002;Zhang et al., 2004;Wang et al., 2019;Ning et al., 2010). DIN concentrations increased from $0.30 \mu \mathrm{mol} \mathrm{L}^{-1}$ to $3.55 \mu \mathrm{mol} \mathrm{L}^{-1}$ in the time from $1982-2009$, while phosphate (from $0.76 \mu \mathrm{mol}$ $\mathrm{L}^{-1}$ to $\left.0.31 \mu \mathrm{mol} \mathrm{L}^{-1}\right)$ and silicate $\left(26.6 \mu \mathrm{mol} \mathrm{L}^{-1}\right.$ to $\left.6.60 \mu \mathrm{mol} \mathrm{L}^{-1}\right)$ concentrations significantly decreased, so that $\mathrm{N} / \mathrm{P}$ increased dramatically (Zhang et al., 2004;Liu et al., 2011). Phytoplankton nutrient limitation in the BHS switched from nitrogen to phosphorus in the period of the 1980s to the 1990s and this limitation pattern persists until the present day (Xu et al., 2010;Liu et al., 2009; Wang et al., 2019).

The total annual water discharge of rivers into BHS is about $68.5 \times 10^{9} \mathrm{~m}^{3} \mathrm{yr}^{-1}$, of which the YR accounts for more than 75\% (Liu et al., 2011). Water exchange time of the YR estuary is only 0.1-0.2 days (Liu et al., 2009), which implies a fast transfer of nutrients into the open BHS and much of these are trapped in Laizhou Bay (Fig. 1) (Zhang et al., 2004). The atmospheric deposition of nitrate $\left(3.42 \times 10^{9} \mathrm{~mol} \mathrm{yr}^{-1}\right)$ in BHS was modelled to be less than riverine nitrate $\left(7.25 \times 10^{9} \mathrm{~mol}^{\mathrm{yr}^{-1}}\right)$, while more ammonium was supplied from atmospheric deposition $\left(6.15 \times 10^{9} \mathrm{~mol} \mathrm{yr}^{-1}\right)$ than from riverine input $\left(0.93 \times 10^{9} \mathrm{~mol}\right.$ $\mathrm{yr}^{-1}$ ) in the 1990s (Zhang et al., 2004). BHS nitrate budgets reported during the last two decades were not completely constrained, because crucial data, such as groundwater discharge or nitrification, were not available (Zhang et al., 2004;Liu et 
al., 2003;Liu et al., 2009; Liu et al., 2011). There are few published nutrient data from the BHS over the last decade, and the terms in the $\mathrm{N}_{\mathrm{r}}$ budget of BHS concerning the quantities of $\mathrm{N}_{\mathrm{r}}$ generated or eliminated by biogeochemical cycling within the basin have not been addressed.

The nitrogen budget and in particular the internal sources and sinks of nitrate can be constrained with a mass-based and dual stable-isotope approach based on $\delta^{15} \mathrm{~N}$ and $\delta^{18} \mathrm{O}$ of nitrate. The combination of data permits tracking of nitrate and quantification of internal cycling of inorganic nitrogen (Sigman et al., 2005; Wankel et al., 2006;Sugimoto et al., 2009;DiFiore et al., 2006; Montoya et al., 2002;Emeis et al., 2010). Stable isotopes of reactive nitrogen have been used to explore nitrogen sources in the eastern Chinese seas (Umezawa et al., 2013;Wang et al., 2016;Liu et al., 2017;Wu et al., 2019;Liu et al., 2020) and the Changjiang Estuary (Yu et al., 2015;Wang et al., 2017; Yang et al., 2018;Chen et al., 2013).

For this study we analyzed water, suspended matter and sediments in the Bohai Sea sampled during the spring and summer seasons for nutrient concentrations, carbon and nitrogen contents, dual isotopes $\left(\delta^{15} \mathrm{~N}\right.$ and $\left.\delta^{18} \mathrm{O}\right)$ of nitrate and $\delta^{15} \mathrm{~N}$ of particulate nitrogen. Aim of the study is to characterize and quantify $\mathrm{N}_{\mathrm{r}}$ sources and sinks, in particular those from internal cycling processes that have not been included in previous budgets (Zhang et al., 2004;Liu et al., 2003;Liu et al., 2009;Liu et al., 2011), to track the fate of $\mathrm{N}_{\mathrm{r}}$ in the present Bohai Sea. The observation data presented here are the basis for a combined mass and isotope balance model, results of which will be a basis for future studies on the rising impact of fast-growing megacities in the Bohai Sea catchment and their possible impact on the adjacent Yellow Sea.

\section{Materials and methods}

\subsection{Sample collection}

Research cruises were carried out by R/V Dongfanghong 2 in spring and summer 2018 with 24 sampling sites in April and 25 sites in August, respectively (Fig. 1). Water samples were taken from several depths by 12 L Niskin bottles attached to a CTD rosette (911plus, Seabird, USA). The water samples were filtered using nucleopore polycarbonate filters $(0.4 \mu \mathrm{m})$ with plastic Nalgene filtration units. The filtered water was collected in Falcon PE tubes $(45 \mathrm{~mL})$, frozen immediately $\left(-20^{\circ} \mathrm{C}\right)$ and kept frozen until analyses in the home laboratory in Germany. Between 1 to $8 \mathrm{~L}$ of water were filtered through pre-weighted $\mathrm{GF} / \mathrm{F}$ filters $\left(0.7 \mu \mathrm{m}, \Phi=47 \mathrm{~mm}\right.$, Sigma Aldrich) which had been pre-combusted at $450^{\circ} \mathrm{C}$ for $4 \mathrm{~h}$. The filters were subsequently dried on board under $45^{\circ} \mathrm{C}$ for 24 hours. Surface sediments were taken with a box corer and surface samples were transferred into plastic bags with a metal spoon, frozen at $-20^{\circ} \mathrm{C}$ and were kept frozen until later analysis in the home lab.

Yellow River water samples were taken from the Kaiyuan floating bridge in Lijin, located $44 \mathrm{~km}$ upstream of the river mouth. Samples were taken in the middle of the river course with a plastic reversing water sampler at 1 meter under the surface. The water samples were filtered immediately for nutrient analysis and collection of suspended particles, and subsequently 
were stored frozen until delivered to the home laboratory. Samples were taken monthly in May, July to November from Yellow River, and in November from Daliao River, Hai River, Luan River and Xiaoqing River (Fig. 1).

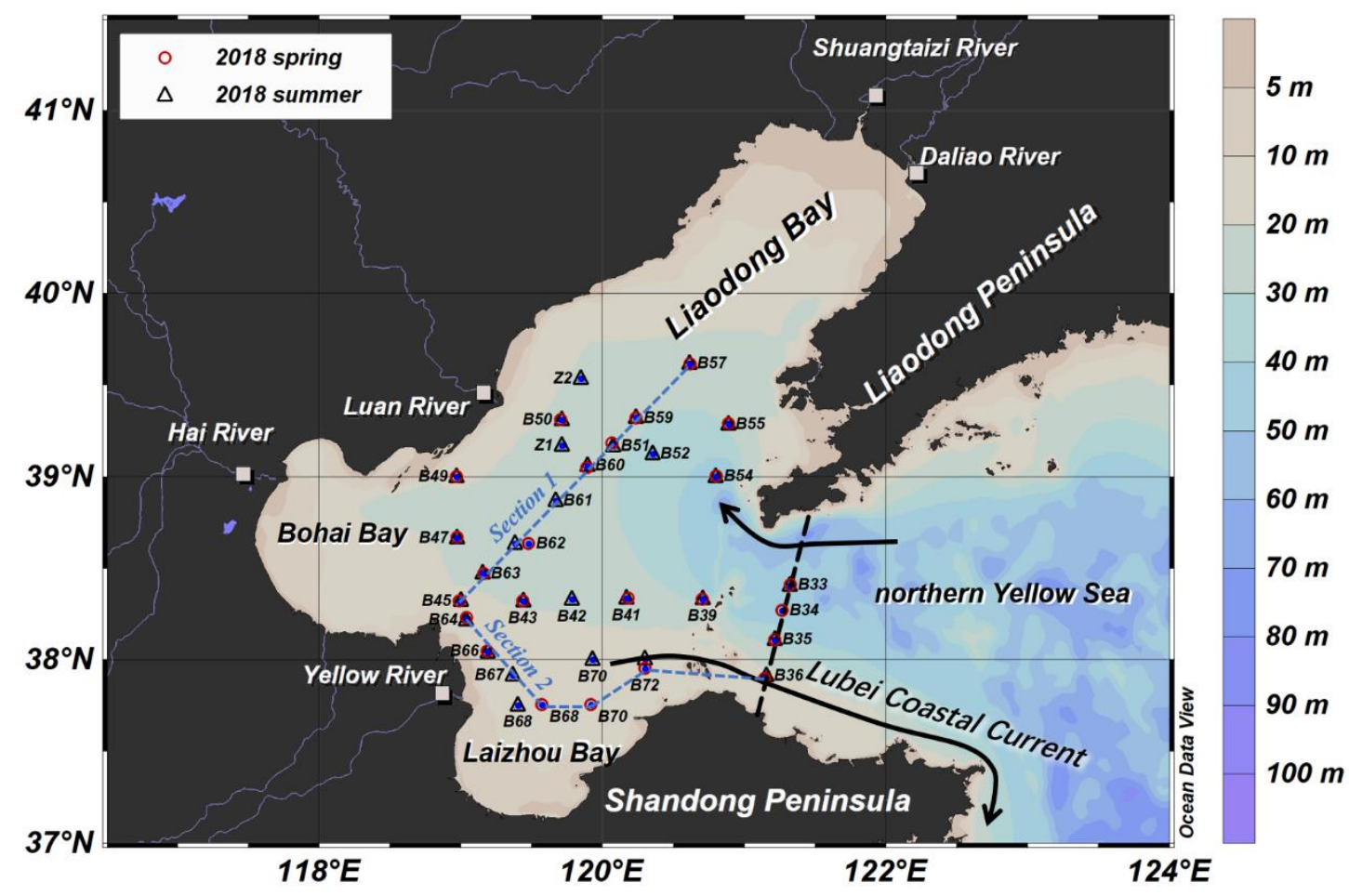

Fig. 1 Sampling sites in Bohai Sea and rivers (Xiaoqing River not shown). Open red circles stand for sampling site in

spring, open blue triangles stand for sampling sites in summer, names of the sites are marked nearby. Black arrows stand for the most significant currents flows in and out of the Bohai Sea. Blue dashed lines strand for two main sections, black dashed line stand for the boundary of our study area.

\subsection{Measurements of nutrients and nitrate isotopes}

Nutrient concentrations were measured with an AutoAnalyzer 3 system (Seal Analytics) using standard colorimetric methods (Grasshoff et al., 2009). The relative error of duplicate sample measurements was below $1.5 \%$ for $\mathrm{NO}_{\mathrm{x}}$ and phosphate concentrations, below $0.3 \%$ for ammonium. The detection limit was $<0.5 \mu \mathrm{mol} \mathrm{kg}{ }^{-1}$ for $\mathrm{NO}_{\mathrm{x}},>0.1 \mu \mathrm{mol} \mathrm{kg}^{-1}$ for $\mathrm{PO}_{4}^{3-}$, and $>0.013 \mu \mathrm{mol} \mathrm{L}^{-1}$ for ammonium.

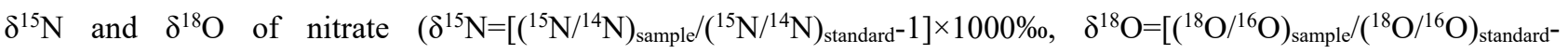
$1051] \times 1000 \%$,) were determined with the denitrifier method (Sigman et al., 2001;Casciotti et al., 2002). Only the samples with nitrate concentrations $>1.7 \mu \mathrm{mol} \mathrm{kg}-1$ were analyzed and $\delta^{15} \mathrm{~N}$ and $\delta^{18} \mathrm{O}$ were analyzed in one sample run. Water samples were 
https://doi.org/10.5194/bg-2020-471

Preprint. Discussion started: 21 December 2020

(c) Author(s) 2020. CC BY 4.0 License.

(c) (i)

injected into a suspension of the denitrifier Pseudomonas aureofaciens with injection volumes adjusted to yield $10 \mathrm{nmol}_{2} \mathrm{O}$. The $\mathrm{N}_{2} \mathrm{O}$ gas was purged by helium into a GasBench 2 (Thermo Finnigan) for purification. Afterwards the $\mathrm{N}_{2} \mathrm{O}$ gas was analyzed by a Delta V Advantage and a Delta V Plus mass spectrometer. Samples were measured in duplicate and the two international standards IAEA-N3 $\left(\delta^{15} \mathrm{~N}_{-N_{3}}=+4.7 \%\right.$, $\left.\delta^{18} \mathrm{O}-\mathrm{NO}_{3}{ }^{-}=+25.6 \%\right)$ and USGS-34 $\left(\delta^{15}{\mathrm{~N}-\mathrm{NO}_{3}}^{-}=-1.8 \%\right.$, $\delta^{18} \mathrm{O}-\mathrm{NO}_{3}{ }^{-}=-$ $27.9 \%$ ) and an internal potassium nitrate standard were measured in each batch. The data were corrected by applying a bracketing correction (Sigman et al., 2009) and the standard deviations of the international and in-house standards was found to be $\leq 0.2 \%$ for $\delta^{15} \mathrm{~N}$ and $\leq 0.5 \%$ for $\delta^{18} \mathrm{O}$. The standard deviations of duplicate samples were in the same range. Nitrite affects the results and was removed following the protocol of Granger and Sigman (2009) whenever $\left[\mathrm{NO}_{2}^{-}\right]$exceeded $5 \%$ of the $\mathrm{NO}_{\mathrm{x}}$ pool. In all other cases, we report combined (nitrite + nitrate) values.

\subsection{Measurements of suspended matters and sediments}

The tared GF/F filters were weighed to calculate the amount of suspended particulate matter (SPM) per liter of water. Total carbon and nitrogen concentrations in SPM and sediment samples were measured by a Euro EA 3000 (Euro Vector SPA) Elemental Analyzer, and SPM samples with high carbon and nitrogen contents and sediments were acidified to measure organic carbon content. The precision of total and organic carbon determination is $0.05 \%$, that of nitrogen is $0.005 \%$, and the standard deviations are less than 0.08 for total and organic carbon and 0.02 for nitrogen. Nitrogen isotope ratios were determined with a FlashEA 1112 coupled to a MAT 252 (Thermo Fisher Scientific) isotope ratio mass spectrometer. The precision of nitrogen isotope analyses is better than $0.2 \%$, and the standard deviation less than 0.03 .

\subsection{Measurements of dissolved oxygen}

The dissolved oxygen (DO) samples were collected, fixed, and titrated on board following the Winkler procedure at an uncertainty level of $<0.5 \%$. A small quantity of $\mathrm{NaN}_{3}$ was added during subsample fixation to remove possible interferences from nitrite (Wong, 2012). The DO saturation (DO\%) was calculated from field-measured DO concentration divided by the DO concentration at equilibrium with the atmosphere which was calculated from temperature, salinity and local air pressure, as per the Benson and Krause $\operatorname{Jr}(1984)$ equation.

\subsection{Hydrodynamic model of nutrient export from BHS to the Yellow Sea}

The regional three-dimensional hydrodynamic Hamburg Shelf Ocean Model, HAMSOM (Backhaus, 1985), was applied in the East China Seas $\left(23^{\circ}-45^{\circ} \mathrm{N}, 117^{\circ}-131^{\circ} \mathrm{E}\right)$ to calculate the water and nutrient transport through the Bohai Strait for the year 2018. The spatial resolution of the model is 2' (approx. $3.7 \mathrm{~km}$ ) with 20 layers in vertical direction, while the calculation time step is 3 minutes. The topography data (resolution of 2') were obtained from marine navigation charts. The meteorological forcing was derived from an hourly ERA5 dataset with a spatial resolution of $0.25^{\circ}$ (CCCS, 2017). The open boundary SSH and the boundary $\mathrm{T}$ and $\mathrm{S}$ data and for the initial $\mathrm{T}$ and $\mathrm{S}$ fields were extracted from the daily Mercator-Ocean dataset (1/12 
https://doi.org/10.5194/bg-2020-471

Preprint. Discussion started: 21 December 2020

(c) Author(s) 2020. CC BY 4.0 License.

(c) (i)

degrees) (Lellouche et al., 2019). 13 partial tides derived from the TPXO8-atlas v1 were superimposed to the SSH along the open boundary (Egbert and Erofeeva, 2002). The observed monthly river discharge were available for the two largest rivers, i.e., Changjiang and Yellow River (China, 2015-2018), while the inputs for the remaining rivers were derived from the Watergap dataset $\left(0.5^{\circ}\right.$, monthly climatology) (Müller Schmied et al., 2014).

Four sites on a north-south section through the Bohai Strait, i.e., B33, B34, B35, and B36, have been selected to represent the open boundary of the Bohai Sea (Fig. 1). The simulated SSH and current velocities (west-east-component) were extracted along this section. In addition, nutrient concentrations were interpolated from the observed data at the four sites to the grid of the hydrodynamic model along the Bohai Strait section. Since the observational data just include spring and summer values, the mean value of nitrate in spring and summer had to be extrapolated to an entire year.

\section{Results}

\subsection{Hydrological properties and nutrients}

\subsubsection{Hydrological properties}

Averages of salinity and temperature in spring were $32.3 \pm 0.5(\mathrm{n}=72)$ and $4.7 \pm 0.8^{\circ} \mathrm{C}(\mathrm{n}=72)$, respectively, and the water column was vertically mixed (Fig. 2 and Fig. 3). The YR discharged relatively warm water and the lowest salinity was observed in the southeast of YR estuary ( site B68, T $>6^{\circ} \mathrm{C}, \mathrm{S}<31$ ). Thus, the Yellow River Diluted Water (YRDW) is here defined as the water off the YR estuary with salinities lower than 31 . In summer, averages of salinity and temperature were $31.6 \pm 0.8(\mathrm{n}=88)$ and $22.4 \pm 4.2^{\circ} \mathrm{C}(\mathrm{n}=88)$, respectively, and the surface layer was stratified. The YRDW extended to an even larger area than in spring caused by high river discharge. The YRDW turned northeast towards LiaoDong Bay into the central BHS in the surface layer $\left(\mathrm{T}>27^{\circ} \mathrm{C}, \mathrm{S}<31\right)$.

The water column oxygen concentrations (see Supplement 1) in the study area in spring and summer were 10.27-11.47

$\mathrm{mg} \mathrm{L}$ and 3.84-8.86 $\mathrm{mg} \mathrm{L}^{-1}$, respectively, and thus much higher than the threshold for water column denitrification $(0.15 \mathrm{mg} / \mathrm{L})$. The detailed results of DO and other parameters are shown in Supplement 2. 

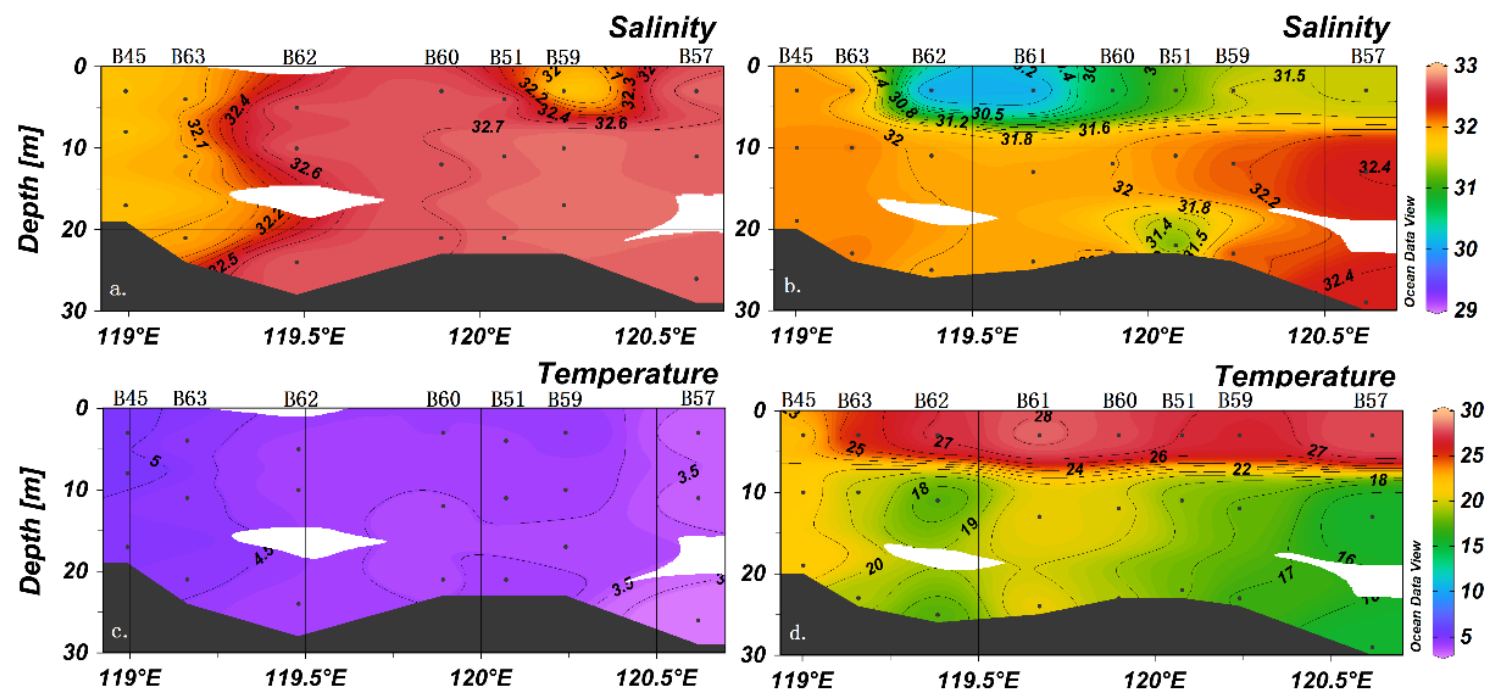

Fig. 2 Temperature $\left({ }^{\circ} \mathrm{C}\right.$ ) and salinity (psu) of section 1 of spring (a. and c.) and summer (b. and d.).

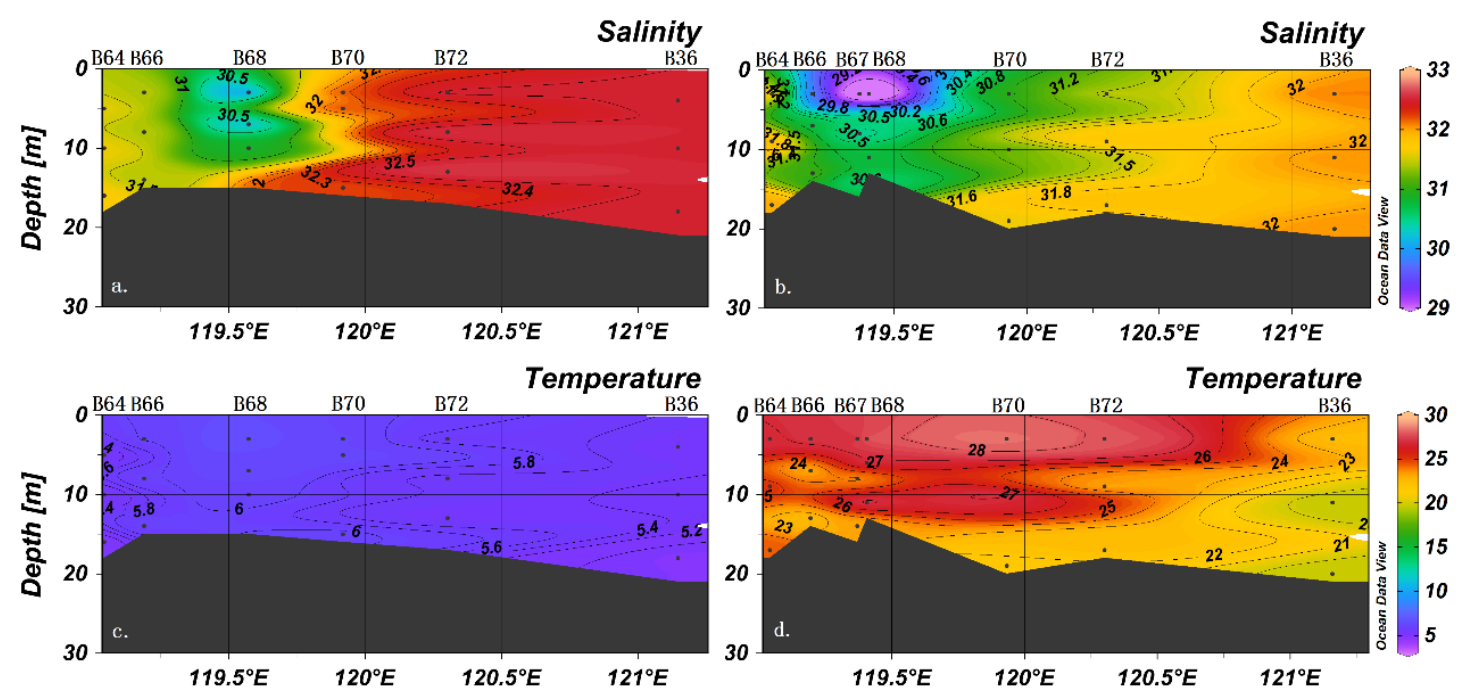

Fig. 3 Temperature $\left({ }^{\circ} \mathrm{C}\right.$ ) and salinity (psu) of section 2 of spring (a. and c.) and summer (b. and d.).

\subsubsection{Nutrient concentrations and distributions}

Nutrient concentrations in spring were vertically uniform, consistent with temperatures and salinities. The YR discharge is indicated by a nitrate maximum at station B68 $(31.0 \mu \mathrm{mol} / \mathrm{L})$ and the lowest observed salinity. Concentrations of $\mathrm{NH}_{4}^{+}$were 
higher than $1 \mu \mathrm{mol} / \mathrm{L}$ and $\mathrm{PO}_{4}^{3-}$ concentrations were lower than $0.4 \mu \mathrm{mol} / \mathrm{L}$ adjacent to $\mathrm{YR}$ estuary, and phosphate increased towards the central BHS (along section 1) and north of Shandong peninsula (along section 2) (Fig. 4 and Fig. 5). The average concentrations of $\mathrm{NO}_{3}^{-}, \mathrm{NO}_{2}^{-}, \mathrm{NH}_{4}^{+}$and $\mathrm{PO}_{4}^{3-}$ of all spring samples were $6.5 \pm 5.8 \mu \mathrm{mol} / \mathrm{L}, 0.2 \pm 0.2 \mu \mathrm{mol} / \mathrm{L}, 0.8 \pm 0.5 \mu \mathrm{mol} / \mathrm{L}$, and $0.4 \pm 0.2 \mu \mathrm{mol} / \mathrm{L}(\mathrm{n}=72)$, respectively.

In summer, nitrate was almost depleted in the BHS except for stations B66 and B67 (included in section 2) located in the tongue of YRDW. $\mathrm{NO}_{2}^{-}$and $\mathrm{NH}_{4}^{+}$, concentration was higher than $2 \mu \mathrm{mol} / \mathrm{L}$ and $5.5 \mu \mathrm{mol} / \mathrm{L}$, respectively, in the same area (Fig. 5). In the central BHS (section 1), the upper $10 \mathrm{~m}$ water layer was nutrient depleted, while concentrations were high in 175 the lower layer. The average concentrations of $\mathrm{NO}_{3}^{-}, \mathrm{NO}_{2}^{-}, \mathrm{NH}_{4}^{+}$and $\mathrm{PO}_{4}^{3-}$ of $1.9 \pm 2.7 \mu \mathrm{mol} / \mathrm{L}, 0.8 \pm 1.1 \mu \mathrm{mol} / \mathrm{L}, 1.6 \pm 1.9$ $\mu \mathrm{mol} / \mathrm{L}$ and $0.1 \pm 0.1 \mu \mathrm{mol} / \mathrm{L}(\mathrm{n}=85)$, respectively.
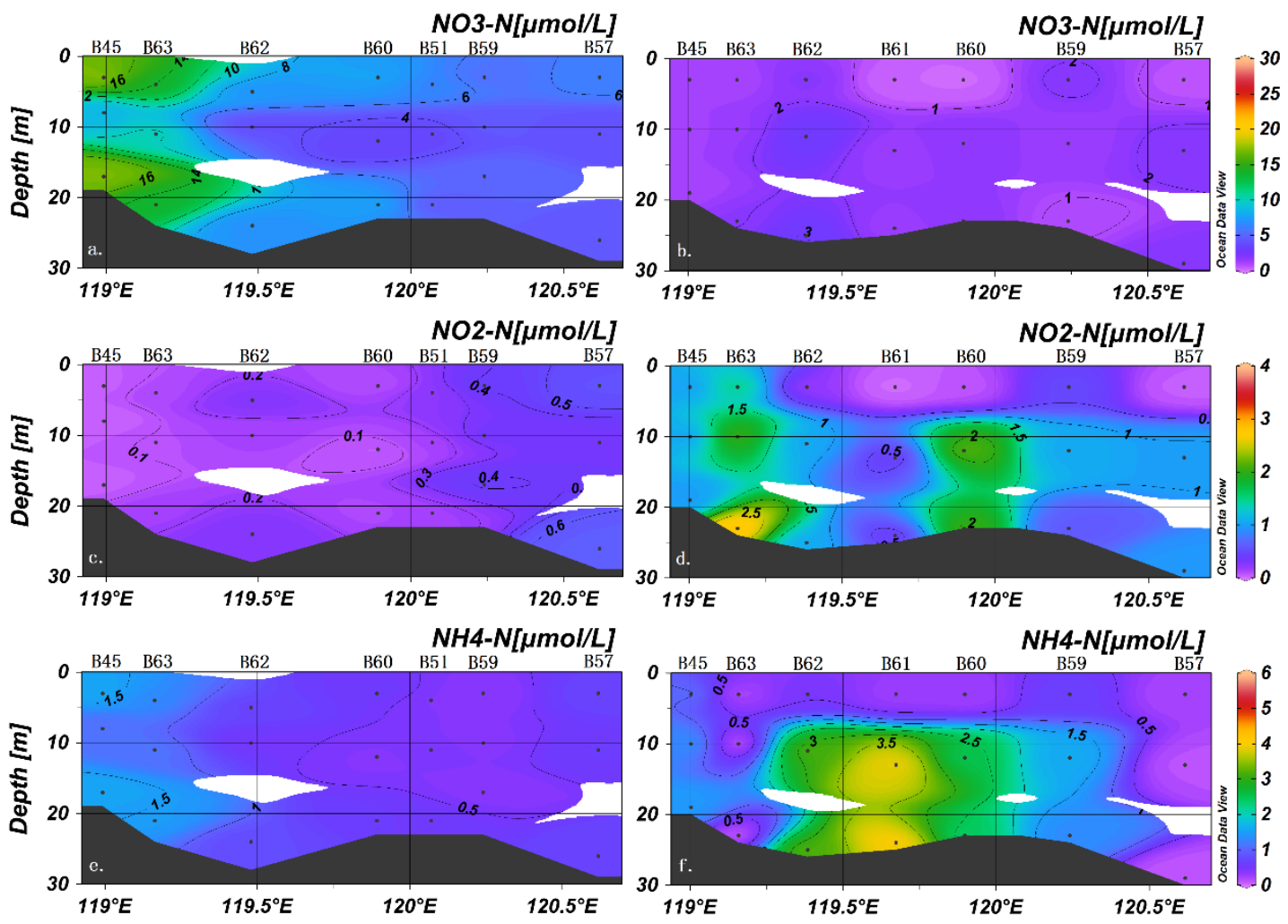

Fig. 4 Nutrients of section 1 ( $\mu \mathrm{mol} / \mathrm{L}$ ) of spring (a., c., and e.) and summer (b., d., and f.). 

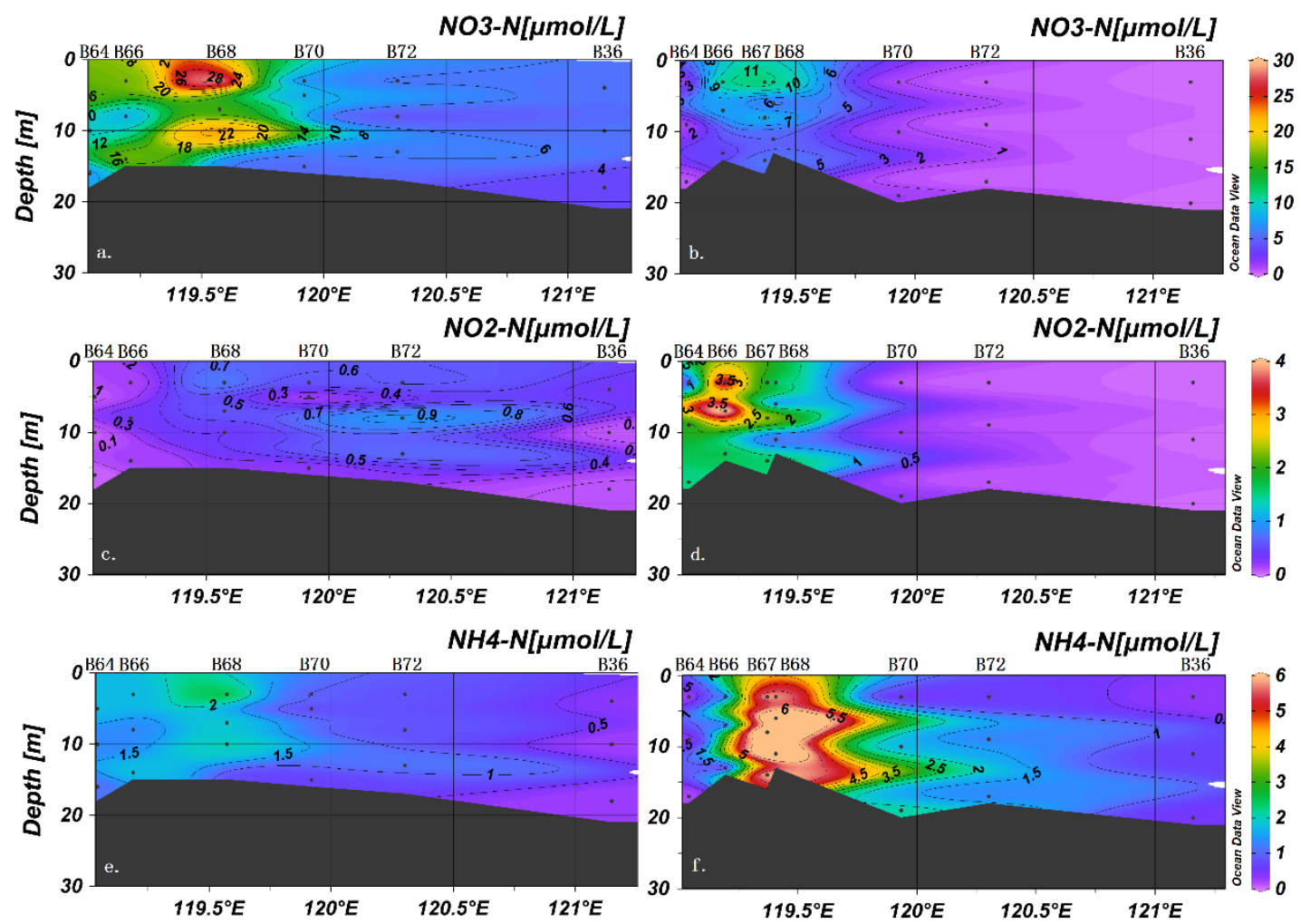

Fig. 5 Nutrients of section 2 ( $\mu \mathrm{mol} / \mathrm{L}$ ) of spring (a., c., and e.) and summer (b., d., and f.).

\subsection{Dual isotopes of nitrate}

In spring, the average values of $\delta^{15} \mathrm{~N}$ and $\delta^{18} \mathrm{O}$ were $7.8 \pm 1.4 \%$ and $12.0 \pm 3.3 \%$ ( $\left.\mathrm{n}=52\right)$, and $\delta^{15} \mathrm{~N}$ and $\delta^{18} \mathrm{O}$ ranged between 5.6\%-10.5\%, and 5.0\%o-20.0\%o, respectively. $\delta^{15} \mathrm{~N}$ and $\delta^{18} \mathrm{O}$ were both vertically homogenous, corresponding to the vertical profile of salinity, temperature, and nitrate. Relatively high $\delta^{15} \mathrm{~N}$ values were observed in the southwestern part of BHS including the areas adjacent to Bohai Bay and Laizhou Bay, which is consistent with high nitrate concentrations. The $\delta^{18} \mathrm{O}$ was inversely related to $\delta^{15} \mathrm{~N}$ with low values near the YR estuary and high values in the northeast of the central BHS and north of Shandong peninsula (Fig. 6 and Fig. 7).

Due to the low nitrate concentration in summer, only a subset of samples could be analyzed and most of these are from the YRDW that had $\left[\mathrm{NO}_{3}^{-}\right]>1.7 \mu \mathrm{mol} / \mathrm{L}$. The average values of $\delta^{15} \mathrm{~N}$ and $\delta^{18} \mathrm{O}$ were $9.9 \pm 3.5 \%(\mathrm{n}=23)$ and $8.7 \pm 3.3 \%$ o $(\mathrm{n}=23)$, and ranged between 3.5\%o-23.9\%o and 3.1\%o-18.4\%o, respectively. The mean value of $\delta^{15} \mathrm{~N}$ was higher than that of spring samples, whereas the $\delta^{18} \mathrm{O}$ value was lower. Relatively high $\delta^{15} \mathrm{~N}$ and $\delta^{18} \mathrm{O}$ values of $23.9 \%$ and $18.4 \%$ were registered in the surface water of YRDW (site B62) and decreased with water depths at increasing nitrate concentrations. 

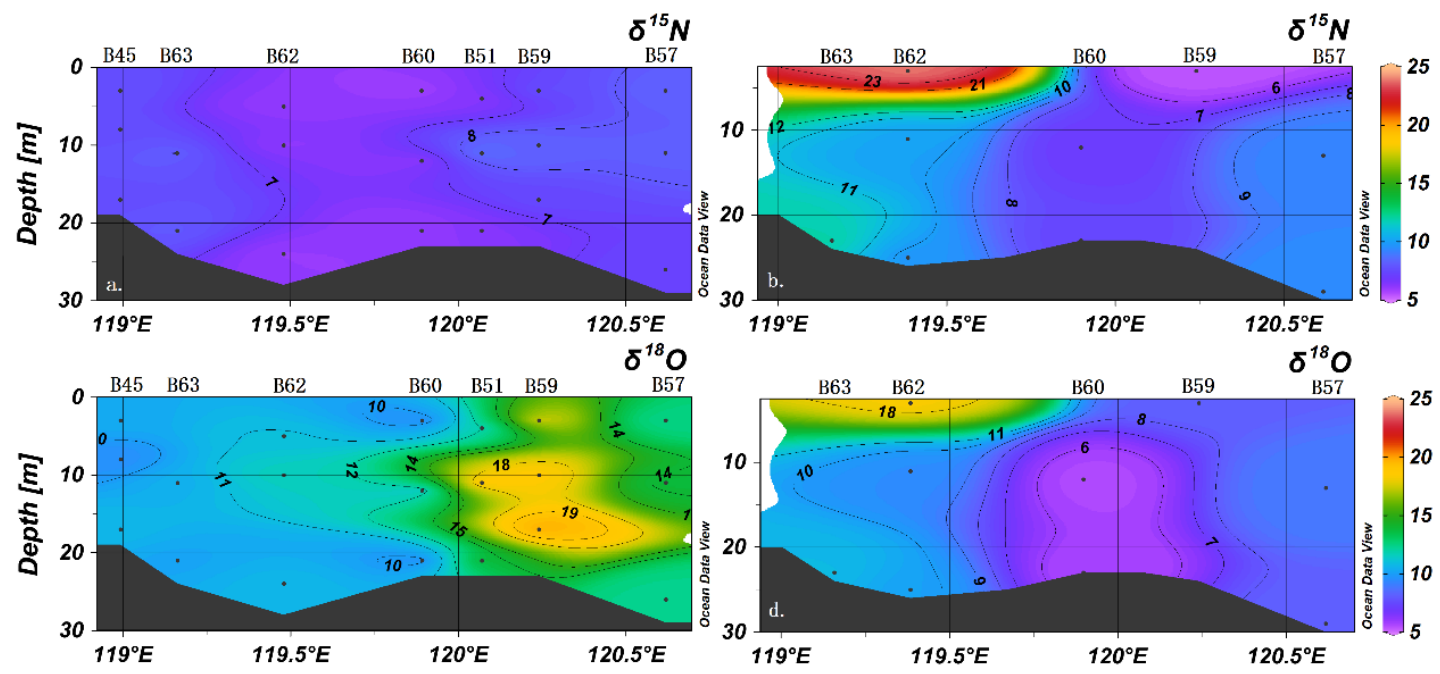

Fig. 6 Nitrate isotopes (\%) of section 1 of spring (a. and c.) and summer (b. and d.)
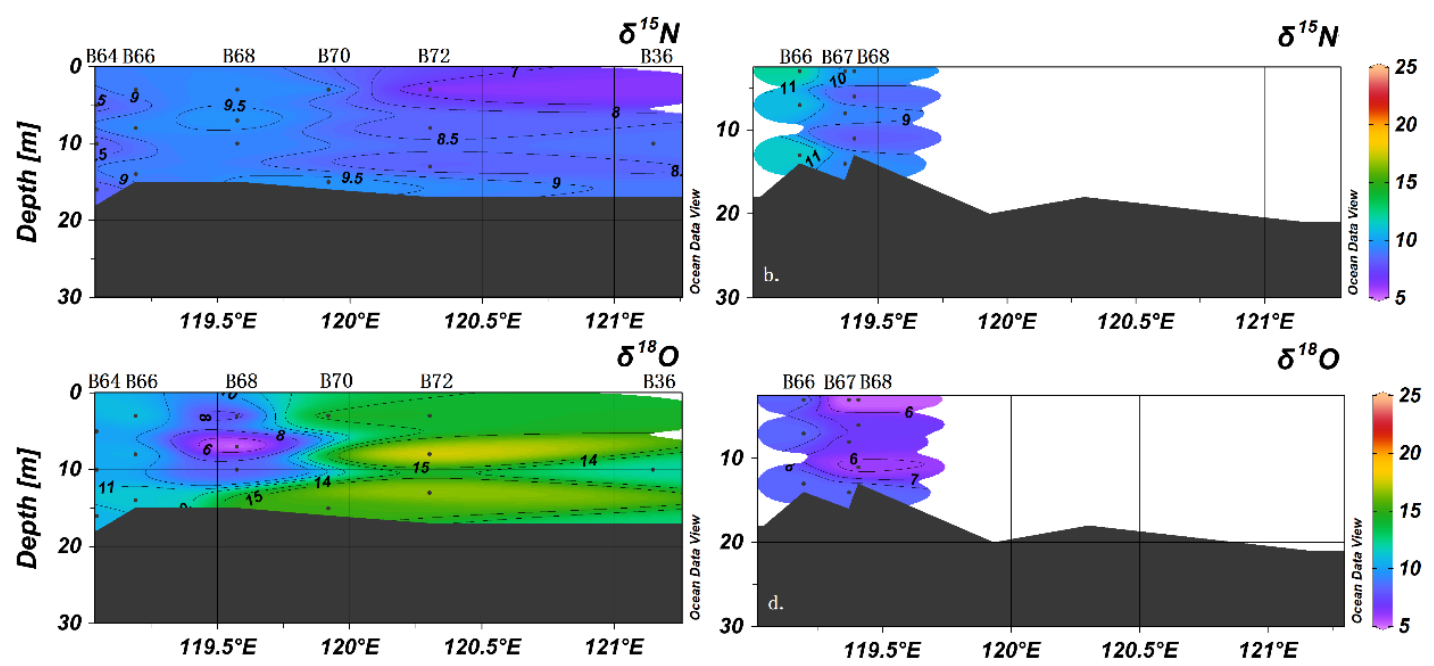

Fig. 7 Nitrate isotopes (\%o) of section 2 of spring (a. and c.) and summer (b. and d.)

\subsection{Suspended particulate matter}

In spring suspended particulate matter (SPM) concentrations were mostly vertically homogenous along both transects with high values (>15 $\mathrm{mg} \mathrm{L}^{-1}$ ) close to the YR mouth (see Supplement 3). $\mathrm{C}_{\mathrm{org}} \%$ and N\% are anti-correlated with SPM concentrations and high values occurred in the central BHS and north of Shandong Peninsula. In summer SPM concentrations were 
https://doi.org/10.5194/bg-2020-471

Preprint. Discussion started: 21 December 2020

(c) Author(s) 2020. CC BY 4.0 License.

(c) (i)

significantly higher than in spring and maxima occurred in deep water off the YR $\left(>30 \mathrm{mg} \mathrm{L}^{-1}\right)$ and in the west part of the BHS. $\mathrm{C}_{\text {org }} \%$ and $\mathrm{N} \%$ maxima occur in surface waters in the eastern Laizhou Bay and the central BHS.

The average $\delta^{15} \mathrm{~N}$ of SPM in spring was $4.8 \pm 0.9 \%$ o $(\mathrm{n}=14)$, with a maximum ( $>6.10 \%$, $\left.\mathrm{n}=3\right)$ south of Luan River. The lowest values were observed in the southern Bohai Strait and northeast of YR estuary. The other samples varied in a narrow range of $3.9 \%{ }_{0}-4.7 \%$ ( $\left.n=11\right)$. In summer, the average of $\delta^{15} \mathrm{~N}$ was $5.7 \pm 0.8 \%$ ( $\left.\mathrm{n}=34\right)$ and ranged from $3.9 \%$ to $7.2 \%$. Systematic variation of $\delta^{15} \mathrm{~N}$ of SPM was barely discernable and only exhibited a weak decline from the YR mouth into the northeastern BHS (section 1) and into the BH Strait (section 2) (see Supplement 3), thus tracking the salinity dilution gradient in the surface layer.

\subsection{The discharge of the Yellow River}

The water discharge of the year 2018 determined at the Lijin hydrography station was $333.8 \times 10^{9} \mathrm{~m}^{3}$ which was by $14 \%$ higher than the multi-year average of $292.8 \times 10^{9} \mathrm{~m}^{3}$ (1952-2015) (MWR, 2019). The monthly mean discharge was $27.80 \pm 20.21 \times 10^{9} \mathrm{~m}^{3} \mathrm{month}^{-1}(\mathrm{n}=12)$, which was higher than the multi-year average value by $14 \%-51 \%$, indicating that in YR basin 2018 was a flood year. The water discharge maximum was from July to October (Fig. 8). During May to November in 2018 (no value for June), the mass fluxes of nitrate, phosphate increased with the water discharge of YR, while the monthly fluxes of nitrite and ammonium exhibited an opposite tendency. $\delta^{15} \mathrm{~N}$ and $\delta^{18} \mathrm{O}$ of YR nitrate ranged from 9.1\%o to $10.9 \%$ and $1.1 \%$ to $3.0 \%$, respectively. The monthly mass-weighted average value of $\delta^{15} \mathrm{~N}$ and $\delta^{18} \mathrm{O}$ were $9.9 \%$ and $1.9 \%$, respectively. $\delta^{15} \mathrm{~N}$ and $\delta^{18} \mathrm{O}$ were positively correlated $\left(\delta^{18} \mathrm{O}=1.04 \times \delta^{15} \mathrm{~N}-8.43, \mathrm{R}^{2}=0.85\right)$, as were $\delta^{15} \mathrm{~N}$ and the monthly mass flux of nitrate $\left(\mathrm{R}^{2}=0.63\right)$. 


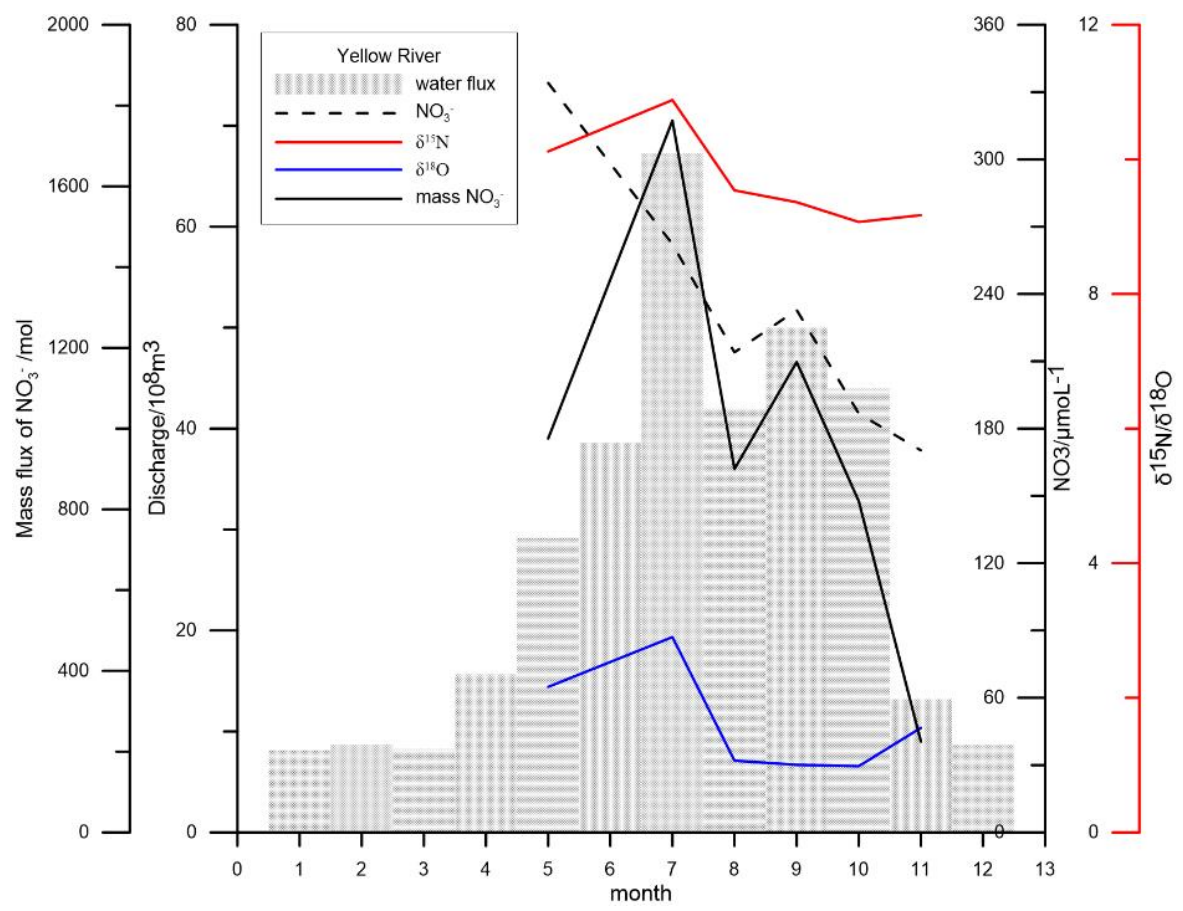

Fig. 8 Monthly variation of water flux (shadowed bar), nitrate concentration (dashed line), mass flux of nitrate (solid line), and dual nitrate isotopes $\left(\delta^{15} \mathrm{~N}\right.$ in red solid line and $\delta^{18} \mathrm{O}$ in blue solid line) of Yellow River in 2018. Water samples were monthly

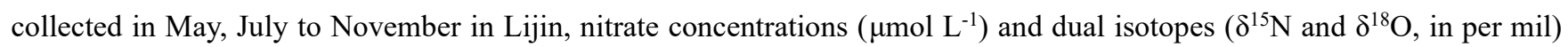
were measured in home laboratory, monthly water flux data $\left(10^{8} \mathrm{~m}^{3}\right)$ are according to the Yellow River Sediment Bulletin 2018 (http://www.yrcc.gov.cn/nishagonggao/2018/index.html\#p=20 ).

\subsection{Nitrate exchange with the Yellow Sea}

Based on current velocities and nutrient concentrations along the section crossing the BH Strait, the annual water and nutrient export from BHS to the Yellow Sea in the year 2018 was calculated to $1.26 \times 10^{-3} \mathrm{~Sv}\left(1 \mathrm{~Sv}=10^{6} \mathrm{~m}^{3} / \mathrm{s}\right)$ and $0.9 \times 10^{9} \mathrm{~mol}$ $\mathrm{yr}^{-1}$, respectively. In this study, the exported nitrate are assumed with the average isotopes values of the $\mathrm{BHS}\left(\delta^{15} \mathrm{~N}=8.9 \%\right.$ and $\delta^{18} \mathrm{O}=10.4 \%$ ).

Making use of the three-dimensional model (HAMSOM) results, it is also possible to determine a spatial distribution of the annual nutrient flux through the Bohai Strait section (Fig. 9). Positive values represent a nutrient flux out of the Bohai Sea, while negative ones indicate a flux into the Bohai Sea. The strongest nutrient export occurs at the southern part of the Bohai Strait, while the major import takes place in the upper $15 \mathrm{~m}$ in the northern Bohai Strait (Fig. 9). 


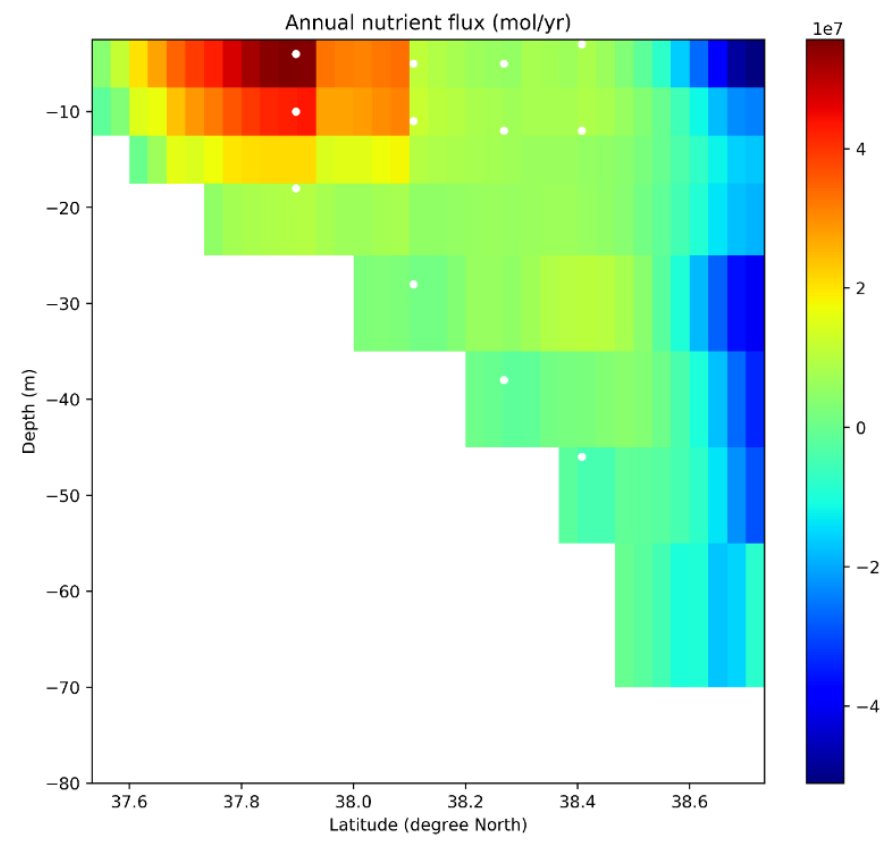

Fig 9 Simulated net fluxes of nitrate $\left(\mathrm{mol} \mathrm{yr}^{-1}\right)$ in the Bohai Strait of the year 2018. White dots are the sampling sites, the color bar is the flux of nitrate $\left(10^{7} \mathrm{~mol} \mathrm{yr}^{-1}\right)$, positive values stand for the export of nitrate from Bohai Sea to Yellow Sea.

\section{Discussion}

\subsection{The hydrographic and nutrients characteristics in spring and summer}

The sampling in early spring occurred during a season of low biological activity so that nutrients behaved almost conservatively. As is indicated by the negative correlations of $N O_{3}^{-}(\mathrm{r}=0-.78, \mathrm{p}<0.01)$, and $\mathrm{NH}_{4}^{+}(\mathrm{r}=-0.79, \mathrm{p}<0.01)$ with salinity, the YR is one of the major sources of these nutrients in the BHS, whereas $\mathrm{PO}_{4}^{3-}$ is contributed by the inflow of saline waters from the YS as indicated by the positive correlation with salinity $(r=0.43, p<0.01)$. Concentrations of nitrate were relatively high in the southern Bohai Strait but low in its northern part, suggesting that in spring nitrate- rich water flows out of BH Strait along the northern shore of Shandong Peninsula in the LCC, while nitrate-depleted water flows in from the northern Yellow Sea via the northern strait (see the discussion of chapter 4.2.5).

In summer, the water is stratified with the thermocline (= halo- and nutricline) at about $8 \mathrm{~m}$ water depth. Nutrients are depleted to trace amounts above the thermocline. In contrast to the other nutrients, phosphate concentrations did not increase with depth in the southwestern part of BHS (i.e. Bohai Bay and Laizhou Bay). Similar to the spring situation, salinity was weakly positively correlated with $\mathrm{PO}_{4}^{3-}(\mathrm{r}=0.29, \mathrm{p}<0.05)$ and $\mathrm{NO}_{2}^{-}(\mathrm{r}=0.32, \mathrm{p}<0.05)$, whereas it was negatively correlated 
with $\mathrm{NO}_{3}^{-} \quad(\mathrm{r}=-0.69, \mathrm{p}<0.01)$ and $\mathrm{NH}_{4}^{+} \quad(\mathrm{r}=-0.37, \mathrm{p}<0.01)$, respectively. The average N/P ratio in BHS in spring and summer was $28.2 \pm 38.2$ and $86.9 \pm 126.3$, respectively, implying that productivity in BHS was phosphorus limited. Thus, diazotrophic $\mathrm{N}_{2}$ fixation is excluded as a significant input of $\mathrm{N}_{\mathrm{r}}$ because of high $\mathrm{N}: \mathrm{P}$ ratios.

\subsection{The main sources and sinks of nitrate in the BHS}

Most of the external and internal sources of nitrate to the BHS are characterized by distinct dual isotope values. These fingerprints combined with mass flux estimates are in the following used to constrain the mass and isotope budget of nitrate in the BHS. Specifically, the role of internal cycling processes can thus be quantified, which were lacking in previous budgets. In the following, each of the sources and sinks is described, along with isotope composition or isotope fractionation associated with cycling processes.

\subsubsection{Riverine inputs}

The main input from this source of BHS $\mathrm{N}_{\mathrm{r}}$ is from the Yellow River and we calculated a nitrate input of YR of $7.95 \times 10^{9}$ mol $\mathrm{yr}^{-1}$, based on the annual average discharge (Yellow River Conservancy Commission of MWR, 2019) and the loadweighted nitrate concentration during our sampling period during the year 2018. The water discharge of the other 7 important rivers (Hai River, Shuangtaizi River, Daliao River, Luan River, Xiaoqing River, Daling River and Xiaoling River) sums up to 59.86 $\times 10^{8} \mathrm{~m}^{3} \mathrm{yr}^{-1}$ (MWR, 2019; Ma et al., 2004; Yu et al., 2018;Zhang et al., 2004). Nitrate fluxes of these rivers were calculated based on water discharge and our nitrate measurements in YR, Hai River, Daliao River, Luan River and Xiaoqing River. Owing to a lack of data on nitrate concentrations of Shuangtaizi River, Daling River and Xiaoling River and considering that these rivers drain basins adjacent to Daliao River, we assume that nitrate concentration of these rivers were same as those of the Daliao River. The total riverine input of nitrate summed up to $9.49 \times 10^{9} \mathrm{~mol}$.

The mass-weighted average annual values for $\delta^{15} \mathrm{~N}$ and $\delta^{18} \mathrm{O}$ of nitrate in these rivers were $10.0 \%$ and $1.3 \%$, respectively, taken here to represent the river nitrate isotopic composition discharged into BHS.

\subsubsection{Submarine ground water input}

The DIN supplied to BHS by submarine groundwater discharge (SGD) flux has been estimated to be 2-10 times the YR discharge (Luo and Jiao, 2016; Peterson et al., 2008; Wang et al., 2015). These fluxes of SGD are a mixture of submarine fresh groundwater discharge (SFGD) and recirculated saline groundwater discharge (RSGD) (Liu et al., 2011;Peterson et al., 2008), but only the freshwater component is relevant as a source for the budget.

The latest estimate of DIN flux for SFGD in Laizhou Bay amounts to 0.57-0.88 of YR input (Wang et al., 2015). We took the average of the SFGD flux (Wang et al., 2015) and the average nitrate concentration of ground water around Laizhou Bay 
https://doi.org/10.5194/bg-2020-471

Preprint. Discussion started: 21 December 2020

(c) Author(s) 2020. CC BY 4.0 License.

(c) (i)

(there is no data on nutrient concentrations of SFGD available so far) (Zhang et al., 2016) to calculate the SFGD inorganic nitrogen flux, which resulted in $3.62 \times 10^{9}$ mol year $^{-1}$. The ratio of $\mathrm{NO}_{3}{ }^{-} /\left(\mathrm{NO}_{3}{ }^{-}+\mathrm{NH}_{4}{ }^{+}\right)$is 0.75 in total SGD (Liu et al., 2011; Chen et al., 2007), so that the nitrate flux of SFGD is estimated at $2.73 \times 10^{9} \mathrm{~mol}$. Due to lack of data on SFGD from the entire BHS, this number was used to represent the input from SFGD to the BHS, which may underestimate the factual value and is only approximately $10 \%$ of previous estimates of the input nitrate for SGD into BHS (Liu et al., 2011) due to the exclusion of RSGD.

Because of pollution and denitrification processes in soils, aquifers and groundwater (Zhang et al., 2013; Chen et al., 2007; Soares, 2000), the value of $\delta^{15} \mathrm{~N}$ and $\delta^{18} \mathrm{O}$ of nitrate in SFGD is more enriched than those of river runoff and this is illustrated by the observed $\delta^{15} \mathrm{~N}$ value of $20.2 \pm 9.0 \%$ ( $\left.\mathrm{n}=19\right)$ of on-land groundwater near the YR delta (Chen et al., 2007). As there are as yet no reported $\delta^{15} \mathrm{~N}$ values of SFGD and RSGD inputs, we decided to take this value as the signal of nitrate $\delta^{15} \mathrm{~N}$ imported by SFGD into the BHS. There are no data available for $\delta^{18} \mathrm{O}$ of nitrate of SFGD, and we will discuss possible constraints in the box model discussion (Sect. 4.3.2).

\subsubsection{Atmospheric deposition}

Combined atmospheric input by wet and dry deposition ranged from $3.14 \times 10^{9} \mathrm{~mol} \mathrm{yr}^{-1}$ to $3.42 \pm 2.29 \times 10^{9} \mathrm{~mol} \mathrm{year}^{-1}$ (Zhang et al., 2004;Liu et al., 2003) We adopted the annual mass of $\mathrm{NO}_{\mathrm{x}}$ deposition for China of $6.2 \mathrm{Tg} \mathrm{yr}^{-1}$ (Zhao et al., 2017) and related this value to the area of the BHS, which results in an annual deposition of $3.6 \times 10^{9} \mathrm{~mol} \mathrm{yr}^{-1}$. Owing to a lack of directly measured data for atmospheric $\mathrm{NO}_{\mathrm{x}}$ the BHS, we adopt $3.42 \times 10^{9} \mathrm{~mol} \mathrm{yr}^{-1}$ (Zhang et al., 2004) as the atmospheric nitrate flux.

The nitrate $\delta^{15} \mathrm{~N}$ values of PM2.5 (fine particulate matter suspended in the air) ranged from 3.5-17.8\%o in northern China (Fan et al., 2019;Zong et al., 2017; Song et al., 2020;Zhang et al., 2019), whereas nitrate $\delta^{15} \mathrm{~N}$ of precipitation ranged from -2.5 to $+0.9 \%$ (Zhang et al., 2008; Chang et al., 2019; Li et al., 2019; Kim et al., 2019). Assuming that PM2.5 is the main component of dry deposition we use a $\delta^{15} \mathrm{~N}$ value of 8.2\%o reported from Beihuangcheng island in Bohai Strait (Zong et al., 2017), while the wet deposition has a $\delta^{15} \mathrm{~N}$ value of $-2.35 \%$ (Chang et al. (2019). Wet deposition in BHS was estimated as $54 \%-68 \%$ of total deposition (Liu et al., 2003;Zhang et al., 2008;Zhao et al., 2017), resulting in a mass-weighted average of BHS atmospheric deposition ranging from $1.03 \%$ to $2.56 \%$, of which the arithmetic mean value of $1.80 \%$ is adopted here.

The nitrate $\delta^{18} \mathrm{O}$ of PM2.5 in BHS ranged from $65.0 \%$ to $88.1 \%$ (seasonally) (Zong et al., 2017), the value in Beijing is $88.3 \pm 6.9 \%$ (Song et al., 2020) and $57.80 \pm 4.23 \%$ in cloud samples of Shandong (Chang et al., 2019). For nitrate $\delta^{18} \mathrm{O}$ of dry deposition, we thus assume a mean value of $80.5 \%$ and that wet deposition has a $\delta^{18} \mathrm{O}$ of $57.8 \%$. These two estimates combined give a ratio of dry and wet deposition in the range of $65.8 \%$ to $68.0 \%$. The arithmetic mean value is $66.9 \%$, which we take to represent the $\delta^{18} \mathrm{O}$ of nitrate deposited from the atmosphere to the BHS. 
The ammonium deposited from the atmosphere is assimilated by phytoplankton and is subsequently entrained into the $\mathrm{N}$ cycle via remineralization and nitrification or is nitrified directly in the water. Thus, the nitrified atmospheric ammonium is included here as a source bearing on $\delta^{15} \mathrm{~N}$ of nitrate in the sea water. The ammonium deposition in BHS was $6.15 \times 10^{9} \mathrm{~mol} \mathrm{yr}^{-}$

${ }^{1}$, which is more than the nitrate deposition of $3.42 \times 10^{9} \mathrm{~mol} \mathrm{yr}^{-1}$ (Zhang et al., 2004).

The atmospheric ammonium has low $\delta^{15} \mathrm{~N}$ values of -6.53 to $-1.2 \%$ (Zhang et al., 2008; Chang et al., 2019). Given that the $\delta^{15} \mathrm{~N}$ value of ammonium of the north China Plain is -1.2\%o (Zhang et al., 2007), and that there is no obvious accumulation of ammonium in the surface layer in the observations, we assume that this isotope value is identical to the $\delta^{15} \mathrm{~N}$ value of nitrified atmospheric ammonium.

The $\delta^{18} \mathrm{O}$ of nitrate from nitrification is roughly 1\%o higher than that of ambient $\mathrm{H}_{2} \mathrm{O}$ (Sigman et al., 2009; DiFiore et al., 2009; Casciotti et al., 2007; Casciotti et al., 2008b). The $\delta^{18} \mathrm{O}$ of $\mathrm{H}_{2} \mathrm{O}$ in the BHS was reported as $-0.67 \% \pm 0.25 \%$ ( $\left.\mathrm{n}=10\right)$ (Kang et al., 1994; Wu, 1991) and thus the $\delta^{18} \mathrm{O}$ of the newly nitrified nitrate should be approximately $0.3 \%$.

\subsubsection{Benthic fluxes}

\subsubsection{Nitrate diffusing from water to sediment}

Benthic fluxes of nutrients have been investigated through incubation experiments and diffusion models (Zhang et al., 2004; Liu et al., 2011) and range from $63.3 \pm 296 \times 10^{6} \mathrm{~mol} / \mathrm{month}$ nitrate diffusing from bottom water into the sediments (Liu et al., 2011) to sediment-water effluxes of $4.28 \times 10^{9}$ mol year $^{-1}$ in the box model of Zhang et al. (2004). The difference of the estimates is probably due to different methods of calculation. For this study we adopted the annual flux from water to sediment as $0.76 \times 10^{9} \mathrm{~mol}_{\text {year }}{ }^{-1}$ (Liu et al., 2011). We assume that diffusion is not accompanied by isotope fractionation, so $\delta^{15} \mathrm{~N}$ and $\delta^{18} \mathrm{O}$ of nitrate diffusing into the sediment was assumed to be the same as the nitrate pool in BHS (8.9\%o and $10.4 \%$, respectively).

\subsubsection{Ammonium diffusing from sediment to water}

The processes of nitrogen cycling in sediments are complex and variable (Lehmann et al., 2004). The degradation of organic matter, nitrification and assimilation are acting under aerobic conditions, whereas denitrification, anammox and dissimilatory nitrate reduction to ammonium (DNRA) are observed under anaerobic conditions. When organic matter is degraded in the surface sediments, part of the produced ammonium diffuses into the overlying bottom water and subsequently is nitrified to nitrite and nitrate under aerobic condition. For our purpose only the ammonium nitrified bears on the seawater nitrate pool. The mean $\delta^{15} \mathrm{~N}$ value of sediment in BHS was 5.4\%o $(\mathrm{n}=20)$, and according to the fractionation factor during organic matter remineralization of $2 \%$ (Möbius, 2013) and subsequent nitrification (see above), the $\delta^{15} \mathrm{~N}$ and $\delta^{18} \mathrm{O}$ of nitrate efflux from sediment are assumed to be $3.4 \%$ and $0.3 \%$, respectively. 


\subsubsection{Sedimentation}

The mass flux of $\mathrm{N}_{\mathrm{r}}$ sedimentation is unknown. In terms of the effects of $\mathrm{N}_{\mathrm{r}}$ sedimentation on nitrate dual isotopes, phytoplankton organisms that assimilate nitrate from the dissolved phase are the main source of sinking particles, so that the $\mathrm{N}$ and $\mathrm{O}$ will be removed from the nitrate pool following the assimilation fractionation factor. Sinking particles in the BHS have a $\delta^{15} \mathrm{~N}$ of $5.2 \%$ o $\left(\delta^{15} \mathrm{~N}_{\text {sink }}\right)$, which integrates multiple processes such as photosynthesis of phytoplankton, heterotrophic synthesis of bacteria, and heterotrophic degradation (remineralization).

There is no observed data of $\delta^{18} \mathrm{O}$ of nitrate removed from the pool during assimilation $\left(\delta^{18} \mathrm{O}_{\text {sink }}\right)$, but this value can be estimate by the assimilation fractionation factor $\left({ }^{18} \varepsilon\right)$. The per mil fractionation factors $\varepsilon$ of $N\left({ }^{15} \varepsilon\right)$ and $\mathrm{O}\left({ }^{18} \varepsilon\right)$ in nitrate during assimilation are generally assumed to be around $5 \%$, so that ${ }^{15} \varepsilon:{ }^{18} \varepsilon=1: 1$. Here we adopt the average of ${ }^{15} \varepsilon$ and ${ }^{18} \varepsilon$ as $5 \%$ (Granger et al., 2010;DiFiore et al., 2009;Liu et al., 2017;Wu et al., 2019;Umezawa et al., 2013;Wang et al., 2016), so that the $\delta^{18} \mathrm{O}$ of nitrate removed from the pool during assimilation $\left(\delta^{18} \mathrm{O}_{\text {sink }}\right)$ should be $5.0 \%$ according to the $\delta^{18} \mathrm{O}(10.0 \%)$ of the dissolved nitrate pool.

\subsection{The nitrate budget in the BHS}

A box model of the nitrate budgets for the Bohai following the LOICZ approach (Zhang et al., 2004) balanced sources and sinks of nitrate in BHS and was updated by several other nitrate budgets for the BHS during last two decades (Zhang et al., 2004;Liu et al., 2003;Liu et al., 2011;Liu et al., 2009). All were, in general, not completely constrained because of a lack of data on some important source or loss terms. We here associate the nitrate isotope compositions of pools, sources, and sinks of nitrogen with a box model of the BHS nitrate in order to improve the understanding of nitrate cycling in the BHS. Finally, based on the combined mass and isotope box model informed by new data on the isotopic composition of nitrate, surface sediment, and suspended particulate nitrogen in the water column discussed above, we propose an updated N-budget that is internally consistent.

\subsubsection{The nitrate budget based on mass fluxes and corresponding $\delta^{15} \mathrm{~N}$ values}

In our hypothesis, the sources of nitrate for BHS are river inputs, submarine fresh ground water input, atmospheric deposition, and remineralization. Most important sinks are net export to the YS, sediment denitrification and particulate matter sedimentation. Assuming the mass and $\mathrm{N}$ isotope of nitrate in the BHS are in steady state, the sources and sinks of nitrate follow the Eq. (1) and Eq. (2):

$\left(m_{\text {atm }}+m_{r}+m_{N}+m_{S F G D}+m_{n t r}\right)-\left(m_{\text {net }}+m_{\text {sink }}+m_{\text {denitr }}\right)=0$

$\left(\delta^{15} N_{a t m} m_{a t m}+\delta^{15} N_{r} m_{r}+\delta^{15} N_{N} m_{N}+\delta^{15} N_{S F G D} m_{S F G D}+\delta^{15} N_{n t r} m_{n t r}\right)-\left(\delta^{15} N_{\text {net }} m_{\text {net }}+\delta^{15} N_{\text {sink }} m_{\text {sink }}+\right.$ $\left.\delta^{15} N_{\text {denitr }} m_{\text {denitr }}\right)=0$ 
where the terms $\mathrm{m}$ with different subscripts refer to the corresponding nitrogen mass fluxes, $m_{\text {atm }}$ refers to atmospherically deposited nitrate, $m_{r}$ refers to river nitrate, $m_{N}$ refers to nitrified ammonium deposited from the atmosphere, $m_{S F G D}$ refers to nitrate in submarine fresh groundwater discharge, $m_{n t r}$ refers to nitrification in the water column. In terms of sinks, $m_{n e t}$ refers to the mass fluxes associated with net export of nitrate from BHS to the YS, $m_{\text {sink }}$ refers to nitrate sedimenting from seawater as particulate $\mathrm{N}$, and $m_{\text {denitr }}$ refers to denitrification in the sediment. The unit of the mass fluxes is $10^{9} \mathrm{~mol}$. The " $\delta^{15} \mathrm{~N}$ " refers to the $\delta^{15} \mathrm{~N}$ value of the $\mathrm{N}$ mass flux which with the same subscripts. As mentioned previously, the mass fluxes for $m_{N}, m_{n t r}, m_{\text {sink }}$ and $\delta^{15} N_{n t r}$ are unknown and need to be constrained.

The range of $\delta^{15} N_{n t r}$ can be constrained by a simplified interior nitrate cycling model. Ammonium links particles and nitrate in this interior cycling, and there are two different sources of remineralised ammonium in seawater. One is ammonium diffusing from the sediment, the other is the ammonification of PN in the water column. The ammonium from remineralization through both processes is then nitrified in the water column and is a source of nitrate. The average $\delta^{15} \mathrm{~N}$ values of PN and sediments in the BHS in our study are 5.2\% and 5.4\%, respectively. The fractionation factor of ammonification of PN and sediment as the first step of generating recycled nitrate are estimated to 3\%o (Sigman and Fripiat, 2019) and 2\%o (Möbius, 2013), respectively. The remineralised ammonium from PN and sediments thus should have $\delta^{15} \mathrm{~N}$ values between $2.2 \%$ and $3.4 \%$.

The ammonium concentrations in the BHS are low in the water column in spring and in the surface layer in summer, indicating that the ammonium from PN mineralization is most likely completely converted to nitrate, so that there is no fractionation effect for this step. Thus, the $\delta^{15} \mathrm{~N}$ value of newly nitrified nitrate from complete nitrification of ammonium generated by PN mineralization is $2.2 \%$. In the case of incomplete nitrification, especially under the thermocline in summer, the newly nitrified nitrate has a $\delta^{15} \mathrm{~N}$ of $0.2 \%$, given a net fractionation factor of nitrification (ammonium to nitrate) of $2 \%$ (Sigman and Fripiat, 2019). In our model below, the assimilation of ammonium originating from SPM remineralization was not included, as its proportion is unknown in the BHS. The simplified model may thus underestimate the input of ${ }^{15} \mathrm{~N}$-depleted nitrogen into the nitrate pool.

Ammonium diffusing out of the sediment will either be mixed into the euphotic layer and subsequently assimilated by the phytoplankton, or nitrified in the water column. The accumulating of ammonium beneath the thermocline was a significant process in summer, as shown by the high nitrite and ammonium concentrations beneath the thermocline. The ratio of these two branching processes is not known in the BHS. If all of the ammonium from sediment is nitrified, the produced nitrate will have a $\delta^{15} \mathrm{~N}$ of $3.4 \%$ (see above). If the ammonium is only partially nitrified (especially in summer beneath the thermocline), the produced nitrate will have a $\delta^{15} \mathrm{~N}$ of $1.4 \%$ at a fractionation factor of nitrification of $2 \%$ (Sigman and Fripiat, 2019). Thus, the $\delta^{15} \mathrm{~N}$ value of the nitrate produced by nitrification $\left(\delta^{15} \mathrm{~N}_{\mathrm{ntr}}\right.$ ) of ammonium from sediment is in the range of $1.4 \%$ to $3.4 \%$. 
Overall, combing the $\delta^{15} \mathrm{~N}$ ranges of PN- and sediment- originated nitrate, the range of $\delta^{15} \mathrm{~N}$ for newly nitrified nitrate is $0.2 \%$ to $3.4 \%$.

\subsubsection{The coupled $\mathrm{N}$ and $\mathrm{O}$ budgets box model of nitrate}

Because the nitrate mass fluxes $m_{N}, m_{n t r}$, and $m_{\text {sink }}$, cannot be segregated only based on $\mathrm{N}$ mass budgets and $\delta^{15} \mathrm{~N}$ values, we turn to the $\delta^{18} \mathrm{O}$ values of the sources and sinks of nitrate for further constraints. Eq. (3) applies if we assume that the oxygen isotope composition of nitrate reflects the steady-state mass fluxes, as does $\delta^{15} \mathrm{~N}$ of the nitrate pool:

$\left(\delta^{18} O_{a t m} m_{a t m}+\delta^{18} O_{r} m_{r}+\delta^{18} O_{n t r} m_{N}+\delta^{18} O_{S F G D} m_{S F G D}+\delta^{18} O_{n t r} m_{n t r}\right)-\left(\delta^{18} O_{\text {net }} m_{\text {net }}+\delta^{18} O_{\text {sink }} m_{\text {sink }}+\right.$ $\left.\delta^{18} O_{\text {denitr }} m_{\text {denitr }}\right)=0$

where the $\delta^{18} \mathrm{O}$ subscripts refer to the nitrate mass flux with the same subscripts. The $\delta^{18} \mathrm{O}$ of different sources and sinks are either fixed values or ranges of values in our own data, or those taken from the literature (Table 1).

According to Eq. (1), (2) and (3), the unknown mass fluxes $m_{N}, m_{n t r}$ and $m_{\operatorname{sink}}$ can be solved by a set of ternary linear equations including the three unknown terms, when appropriate boundary values of $\delta^{15} \mathrm{~N}_{\text {ntr }}$ and $\delta^{18} \mathrm{O}_{\text {SFGD }}$ are chosen. $\delta^{15} \mathrm{~N}_{\text {ntr }}$ ranged in $0.2 \%$ to $3.4 \%$ as discussed in Sect. 4.3.1, whereas $\delta^{18} \mathrm{O}_{\mathrm{SFGD}}$ is a crucial term without any data or literature constraint. As the only constraint, $\delta^{18} \mathrm{O}_{\mathrm{SFGD}}$ is expected to be higher than the value of nitrate imported from the rivers $\left(\delta^{18} \mathrm{O}_{\mathrm{r}}=1.3 \%\right.$ ) due to the fractionation associated with denitrification in the anaerobic aquifers (see 4.2.2). The results can be summed up in three different cases:

(1)When setting the value of $\delta^{15} \mathrm{~N}_{\text {ntr }}$ to $3.4 \%$, we obtain estimates for $m_{N}$ that range from 0.00 to $1.31 \times 10^{9} \mathrm{~mol}_{\text {year }}{ }^{-1}$, for $m_{n t r}$ in the range of 32.57 to $38.69 \times 10^{9} \mathrm{~mol} \mathrm{year}^{-1}$ and $m_{\text {sink }}$ in the range of 47.87 to $52.68 \times 10^{9} \mathrm{~mol}^{-1}$ year ${ }^{-1}$. The corresponding values of $\delta^{18} \mathrm{O}_{\mathrm{SFGD}}$ range from $1.3 \%$ to $16.3 \%$, and the upper range of $\delta^{18} \mathrm{O}_{\mathrm{SFGD}}$ yields $m_{N}=0.0$ due to the assumption that any mass flux must be equal or greater than 0 .

(2) When we choose a $\delta^{15} \mathrm{~N}_{\text {ntr }}$ value of 3.2\%o and 3.0\%, respectively, to explore effects of the methodological error of $\delta^{15} \mathrm{~N}$ for our isotope method ( $0.2 \%$, see Sect. 2.2), again under the premise that the mass fluxes are positive numbers, results in $m_{N}$, $m_{n t r}$ and $m_{\text {sink }}$ estimates in a narrower range than when $\delta^{15} \mathrm{~N}_{\text {ntr }}$ is $3.4 \%$; these results are not shown.

(3) $\delta^{15} \mathrm{~N}_{\text {ntr }}$ values lower than $3.0 \%$ result in $\delta^{18} \mathrm{O}_{\mathrm{SFGD}}$ lower than $1.3 \%$, which is highly unlikely.

Thus, reasonable solutions only are reached when $\delta^{15} \mathrm{~N}_{\text {ntr }}$ is between 3.4\%o and 3.0\%. The results of the budget are shown in Fig. 10 and Table 1, respectively. 


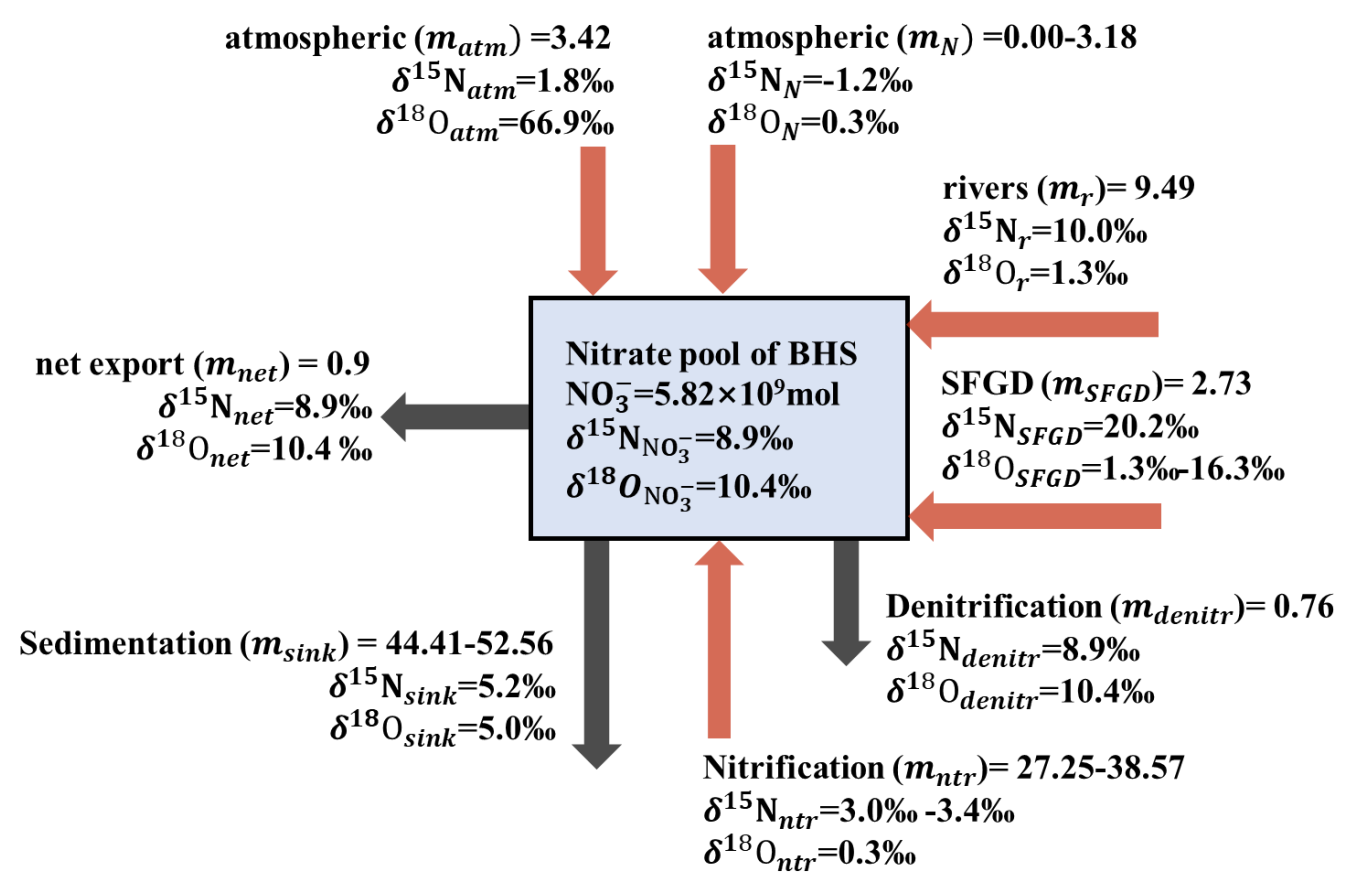

Fig. 10 The budgets and the corresponding dual isotope values of nitrate in the BHS 2018. The terms included are discussed in the text in section 4.3. The unit of mass flux is $10^{9} \mathrm{~mol} \mathrm{yr}^{-1}$. 


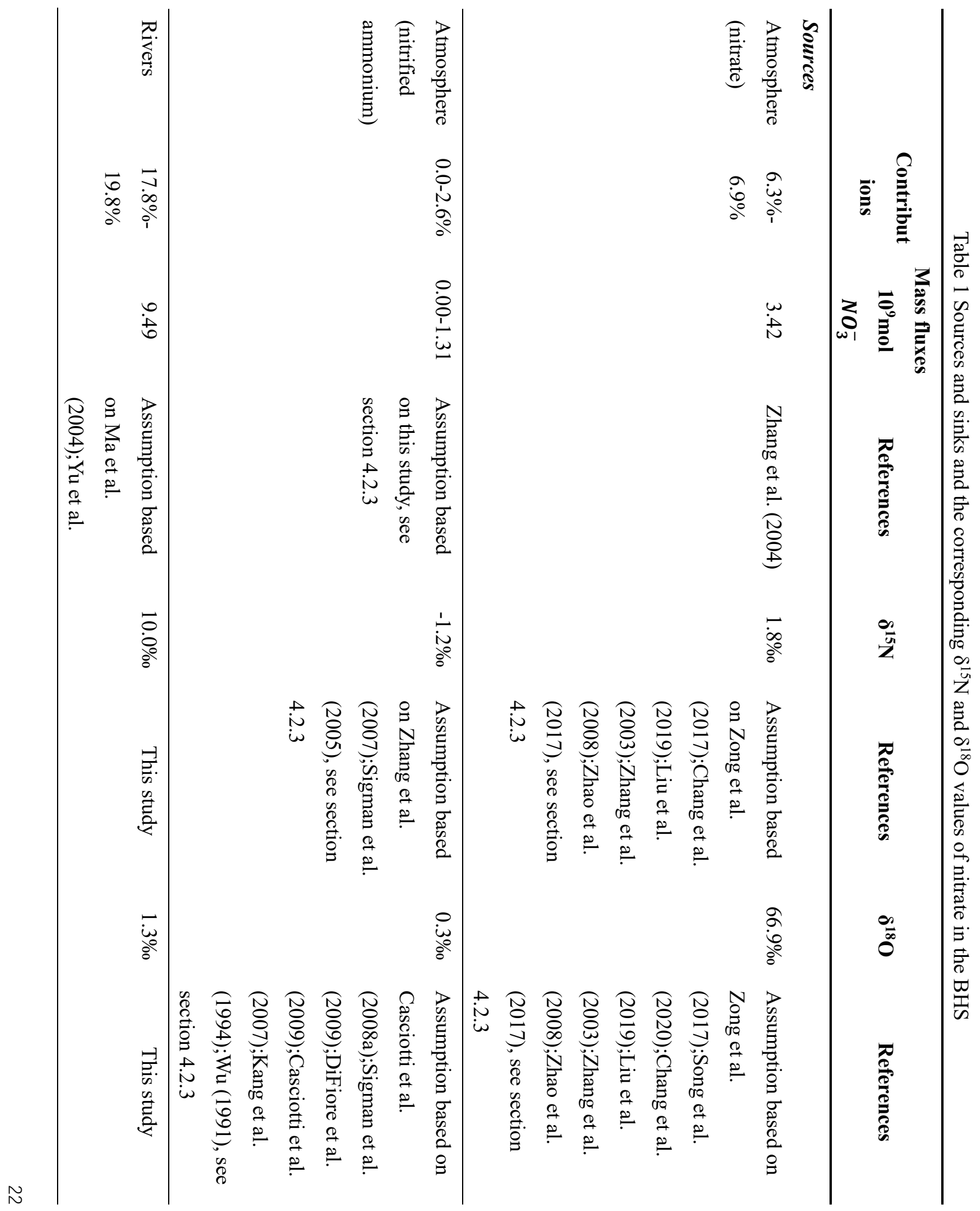



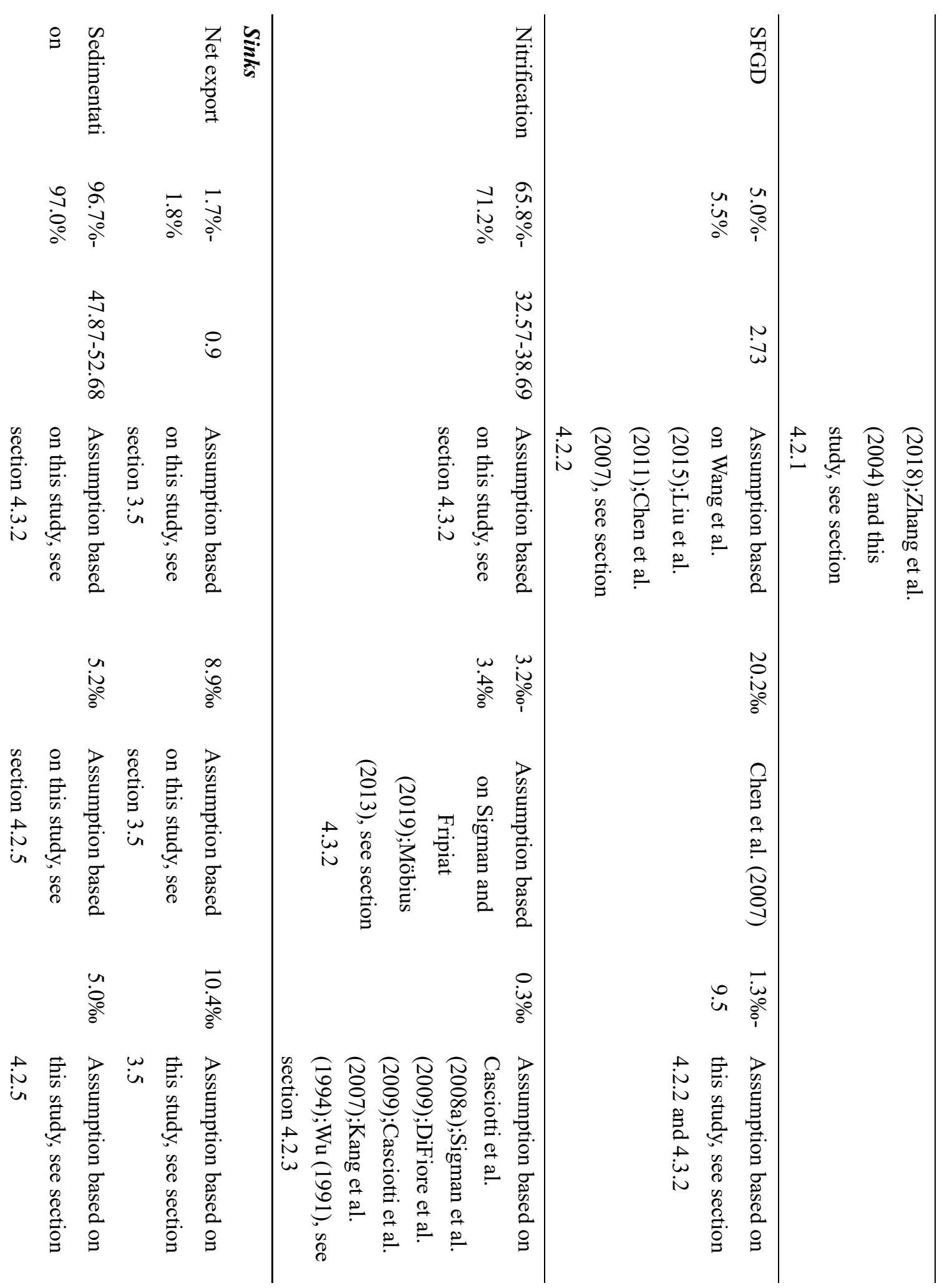
https://doi.org/10.5194/bg-2020-471

Preprint. Discussion started: 21 December 2020

(c) Author(s) 2020. CC BY 4.0 License.

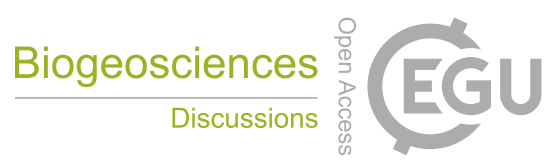

(c) (1)

ले

$\stackrel{\circ}{\sigma}$

in $\frac{\vec{a}}{\dot{a}^{\circ}}$

巨.

9

$\stackrel{2}{2}$

กิ

巨

$\infty$
¿
¿

\&)

ڤ. ङ

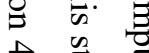

$\dot{i}$ 芑

is

$\begin{array}{lll}\text { L } & \text { : } \\ 0 & 0 \\ 0 & 0\end{array}$

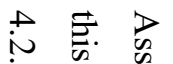

$\rightarrow$ 告

运

\&

命 है

足. 
The mass flux of nitrate $\left(m_{N}\right)$ originating from nitrification of atmospheric ammonium ranges from 0.00 to $3.18 \times 10^{9} \mathrm{~mol}$ year $^{-1}$ and accounts for up to $51.7 \%$ of the total ammonium deposition $\left(6.15 \times 10^{9}\right.$ mol year $^{-1}$; Zhang et al. (2004). This in turn implies that most of the atmospherically deposited ammonium is directly assimilated rather than nitrified to nitrate. This agrees with phytoplankton preference to assimilate ammonium rather than nitrate (Glibert et al., 2016). The bulk of internal sources of nitrate originates from nitrification in the water column (from water column ammonification and ammonium diffusing from sediment). This single source $\left(m_{n t r}\right)$ accounts for $59.1 \%-71.2 \%$ of the total sources of nitrate in BHS and appears to be much more important than in other coastal environments. For example, between $15 \%-27 \%$ of productivity was supported by nitrified ammonium in the seawater in Monterey Bay (Wankel et al., 2007). Likewise, nitrification supplied 34\% of the surface nitrate in the eastern Hainan Island, which like Monterey Bay is also an upwelling area (Chen et al., 2020). This indicates that nitrate regeneration by nitrification may play a more important role in shallow and land-input dominated marginal seas than in upwelling dominated marine settings.

\subsubsection{Assessment of model uncertainties}

The uncertainties of the modeled nitrate mass and isotope budget lie essentially in some of the mass flux estimates and in possibly erroneous assumptions on values of $\delta^{15} \mathrm{~N}$ and $\delta^{18} \mathrm{O}$ in some of the sources and sinks. The mass flux of atmospheric deposition of nitrate is reliable, because differences in estimates from previous studies are quite small. There may be small deviations of $\delta^{15} \mathrm{~N}_{\mathrm{atm}}$ and $\delta^{18} \mathrm{O}_{\text {atm }}$ due to the combination of data for wet and dry deposition sampled separately by different methods, The largest uncertainties in the nitrate budget are associated with SFGD, in terms of both the mass flux $\left(m_{S F G D}\right)$ and the nitrate isotopes $\left(\delta^{15} \mathrm{~N}_{\mathrm{SFGD}}\right.$ and $\left.\delta^{18} \mathrm{O}_{\mathrm{SFGD}}\right)$, for which better estimates are needed. Furthermore, underestimation of sources of nitrate with low $\delta^{15} \mathrm{~N}$ and $\delta^{18} \mathrm{O}$ values cannot be excluded, such as the share of remineralised ammonium (from sinking particles and diffusing out of sediment) assimilated directly by phytoplankton.

\subsubsection{Biogeochemical implications of the box model}

In other coastal eutrophic regions, such as the North Sea, a high $\delta^{15} \mathrm{~N}$ of river nitrate is reflected in a halo of high $\delta^{15} \mathrm{~N}$ in surface sediments in offshore areas (Pätsch et al., 2010). In the Bohai Sea, such an isotopic halo of river-borne eutrophication is not observed despite similar water exchange rates of 1-2 years ( $\mathrm{Li}$ et al., 2015;Serna et al., 2010) and similarly isotopically enriched river inputs. We speculate that the lack of a fingerprint of river nitrate in the $\mathrm{d}^{15} \mathrm{~N}$ of sediments of BHS may be masked by active nitrification and atmospheric deposition that rapidly eradicate and homogenise spatial gradients.

Despite the uncertainties that are related to the box model approach, combining mass and isotope budgets of nitrate sources and sinks is clearly superior to solely nitrate mass balance considerations, especially when it comes to segregating the anthropogenic nitrate and the recycled nitrate inputs. It is of note that the Bohai Sea does not appear to pass on significant 
amounts of nitrate to the adjacent northern Yellow Sea, so that the effects of excessive loading of this shallow mixing zone between land and ocean with anthropogenic nitrogen are yet mitigated by internal cycling processes.

\section{Conclusions}

Rivers contributed 17.5\%-20.6\% and the combined terrestrial runoff (including submarine discharge of nitrate with fresh ground water) account for $22.6 \%-26.5 \%$ of the total $\mathrm{N}_{\mathrm{r}}$ input to the BHS. Atmospheric input contributes $6.3 \%-7.4 \%$ of nitrate to the BHS. Nitrification contributes $59.1 \%-71.2 \%$ of the total nitrate, indicating an unusually active interior nitrogen cycling of in the BHS. Nitrate was mainly trapped in the BHS and only very little was exported to the YS (only $1.7 \%-2.0 \%$ ). Furthermore, nitrate was rather assimilated than exported to the YS along the main transport pathway Lubei Coastal Current, effectively retaining $\mathrm{N}_{\mathrm{r}}$ in BHS. Sedimentation trapped $96.4 \%-96.9 \%$ of nitrate inputs, whereas denitrification was only active in the sediments that removed $1.4 \%-1.7 \%$ of nitrate from the pool. Seasonal biogeochemical variations were observed in the BHS in that dissolved inorganic nitrogen increased during summer under the thermocline, implying significant biological regeneration. If the interior cycling increases, for instance fueled by increased terrestrial and atmospheric $\mathrm{N}_{\mathrm{r}}$ inputs, respiration coupled to organic matter and $\mathrm{N}$ recycling will increase and water-column hypoxia could consequently spread in the future and compromise ecosystems in the BHS. Whether this will invigorate water-column denitrification to balance the additional inputs is an open question, as is the capacity of BHS as a nitrate buffer between the growing source of $\mathrm{N}_{\mathrm{r}}$ on land and the open ocean.

\section{Methods Appendix:}

Nitrate was reduced to nitrite with a copperized cadmium column first. The nitrite ions reacted with sulfanilamide and N1-naphthylethylendediamine (NEDD) to form red azo dye, and then measured at 520-560nm. Phosphate determination followed the method of Murphy and Riley (Murphy and Riley, 1962). Under acid conditions a phosphomolybdic complex was formed of ortho- phosphate, antimony and molybdate ions (Wurl, 2009). Followed by the reduction of ascorbic acid, the blue colour complex was measured at $880 \mathrm{~nm}$. The sample with ammonium is reacted with o-phthalaldehyde (OPA) at $75^{\circ} \mathrm{C}$ in the presence of borate buffer and sodium sulfite to form a fluorescent species proportional to the ammonia concentration. The fluorescence is measured at $460 \mathrm{~nm}$ following excitation at $370 \mathrm{~nm}$ (Kérouel and Aminot, 1997). Silicate is reacted with ammonium molybdate to silicomolybdate, and reduced in acidic solution to molybdenum blue by ascorbic acid (Grasshoff et al., 2009).

\section{Data availability}

Data are prepared to be uploaded to the Pangaea database (https://doi.pangaea.de/ ). 
https://doi.org/10.5194/bg-2020-471

Preprint. Discussion started: 21 December 2020

(c) Author(s) 2020. CC BY 4.0 License.

(c) (i)

\section{The contribution description:}

BG and KCE designed the study. ST collected the samples on board. JT and YL supported the sampling on cruises and field trips. ST, NL, and TS analyzed samples. TX and WZ supplied the dissolved oxygen data. WL ran the HAMSOM model and calculated water mass exchanges. ST, BG, KCE and KD interpreted the data. ST prepared the manuscript with input from all co-authors.

\section{Competing interests}

The authors declare that they have no conflict of interest

\section{Acknowledgment:}

The study was part of the project FINGBOYEL (03F07686B) carried out within the MEGAPOL consortium and financed by the German Federal Ministry of Education and Research (BMBF). We thank the crew of the Chinese research vessel Dongfanghong 2 for their support of our work on board. We are indebted to Yuan Li from Yantai Institute of Coastal Zone

Research for sampling the Yellow River. We thank Markus Ankele and Frauke Langenberg for their support of the nutrient and stable isotope analyses.

\section{References}

Backhaus, J. O.: A three-dimensional model for the simulation of shelf sea dynamics, Dtsch. Hydrogr. Zetischrift, 38, 165-187, https://doi.org/10.1007/BF02328975, 1985.

505 Benson, B. B., and Krause Jr, D.: The concentration and isotopic fractionation of oxygen dissolved in freshwater and seawater in equilibrium with the atmosphere 1, Limnol. Oceanogr., 29, 620-632,

https://doi.org/10.4319/lo.1984.29.3.0620, 1984.

Casciotti, K., Trull, T., Glover, D., and Davies, D.: Constraints on nitrogen cycling at the subtropical North Pacific Station ALOHA from isotopic measurements of nitrate and particulate nitrogen, Deep Sea Research Part II: Topical

510 Studies in Oceanography, 55, 1661-1672, 2008a.

Casciotti, K. L., Sigman, D. M., Hastings, M. G., Böhlke, J., and Hilkert, A.: Measurement of the oxygen isotopic composition of nitrate in seawater and freshwater using the denitrifier method, Anal. Chem., 74, 4905-4912, https://doi.org/10.1021/ac020113w, 2002.

Casciotti, K. L., Böhlke, J. K., Mcllvin, M. R., Mroczkowski, S. J., and Hannon, J. E.: Oxygen isotopes in nitrite: Analysis, 515 calibration, and equilibration, Anal. Chem., 79, 2427-2436, https://doi.org/10.1021/ac061598h, 2007.

Casciotti, K. L., Trull, T. W., Glover, D. M., and Davies, D.: Constraints on nitrogen cycling at the subtropical North Pacific Station ALOHA from isotopic measurements of nitrate and particulate nitrogen, Deep Sea Research Part II: Topical Studies in Oceanography, 55, 1661-1672, https://doi.org/10.1016/j.dsr2.2008.04.017, 2008b. 
https://doi.org/10.5194/bg-2020-471

Preprint. Discussion started: 21 December 2020

(c) Author(s) 2020. CC BY 4.0 License.

(c) (i)

Chang, Y., Zhang, Y. L., Li, J., Tian, C., Song, L., Zhai, X., Zhang, W., Huang, T., Lin, Y. C., Zhu, C., Fang, Y., Lehmann, M.

F., and Chen, J.: Isotopic constraints on the atmospheric sources and formation of nitrogenous species in clouds influenced by biomass burning, Atmospheric Chemistry and Physics, 19, 12221-12234, https://doi.org/10.5194/acp19-12221-2019, 2019.

Chen, C.-T. A.: Chemical and physical fronts in the Bohai, Yellow and East China seas, J. Mar. Syst., 78, $394-410$, https://doi.org/10.1016/j.jmarsys.2008.11.016, 2009.

525 Chen, F., Chen, J., Jia, G., Jin, H., Xu, J., Yang, Z., Zhuang, Y., Liu, X., and Zhang, H.: Nitrate $\delta 15 \mathrm{~N}$ and $\delta 180$ evidence for active biological transformation in the Changjiang Estuary and the adjacent East China Sea, Acta Oceanol. Sin., 32, 11-17, DOI: 10.1007/s13131-013-0294-4, 2013.

Chen, F., Lao, Q., Zhang, S., Bian, P., Jin, G., Zhu, Q., and Chen, C.: Nitrate sources and biogeochemical processes identified using nitrogen and oxygen isotopes on the eastern coast of Hainan Island, Cont. Shelf Res., 104209, https://doi.org/10.1016/j.csr.2020.104209, 2020.

Chen, J., Taniguchi, M., Liu, G., Miyaoka, K., Onodera, S.-i., Tokunaga, T., and Fukushima, Y.: Nitrate pollution of groundwater in the Yellow River delta, China, Hydrogeol. J., 15, 1605-1614, 10.1007/s10040-007-0196-7, 2007. China, M. o. W. R. o.: China Water Resources Bulletin, China Water \& Power Press, Beijing, 2015-2018.

DiFiore, P. J., Sigman, D. M., Trull, T. W., Lourey, M. J., Karsh, K., Cane, G., and Ho, R.: Nitrogen isotope constraints on subantarctic biogeochemistry, J. Geophys. Res.-Oeans, 111, https://doi.org/10.1029/2005JC003216, 2006.

DiFiore, P. J., Sigman, D. M., and Dunbar, R. B.: Upper ocean nitrogen fluxes in the Polar Antarctic Zone: Constraints from the nitrogen and oxygen isotopes of nitrate, Geochem. Geophys. Geosyst., 10,

https://doi.org/10.1029/2009GC002468, 2009.

Egbert, G. D., and Erofeeva, S. Y.: Efficient inverse modeling of barotropic ocean tides, J. Atmos. Ocean. Tech., 19, 183-204, https://doi.org/10.1175/1520-0426(2002)019<0183:EIMOBO>2.0.CO;2, 2002.

Emeis, K. C., Mara, P., Schlarbaum, T., Möbius, J., Dähnke, K., Struck, U., Mihalopoulos, N., and Krom, M.: External N inputs and internal $\mathrm{N}$ cycling traced by isotope ratios of nitrate, dissolved reduced nitrogen, and particulate nitrogen in the eastern Mediterranean Sea, J. Geophys. Res.-Biogeo., 115, https://doi.org/10.1029/2009JG001214, 2010. Fan, M.-Y., Zhang, Y.-L., Lin, Y.-C., Chang, Y.-H., Cao, F., Zhang, W.-Q., Hu, Y.-B., Bao, M.-Y., Liu, X.-Y., Zhai, X.-Y., Lin, X., Zhao, Z.-Y., and Song, W.-H.: Isotope-based source apportionment of nitrogen-containing aerosols: A case study in an industrial city in China, Atmos. Environ., 212, 96-105, https://doi.org/10.1016/j.atmosenv.2019.05.020, 2019.

Fowler, D., Coyle, M., Skiba, U., Sutton, M. A., Cape, J. N., Reis, S., Sheppard, L. J., Jenkins, A., Grizzetti, B., and Galloway, J. N. J. P. T. o. t. R. S. B. B. S.: The global nitrogen cycle in the twenty-first century, 368, 20130164, 550 https://doi.org/10.1098/rstb.2013.0164, 2013.

Glibert, P. M., Wilkerson, F. P., Dugdale, R. C., Raven, J. A., Dupont, C. L., Leavitt, P. R., Parker, A. E., Burkholder, J. M., and Kana, T. M.: Pluses and minuses of ammonium and nitrate uptake and assimilation by phytoplankton and 
https://doi.org/10.5194/bg-2020-471

Preprint. Discussion started: 21 December 2020

(c) Author(s) 2020. CC BY 4.0 License.

implications for productivity and community composition, with emphasis on nitrogen-enriched conditions, Limnol. Oceanogr., 61, 165-197, https://doi.org/10.1002/Ino.10203, 2016.

Granger, J., and Sigman, D. M.: Removal of nitrite with sulfamic acid for nitrate $\mathrm{N}$ and $\mathrm{O}$ isotope analysis with the denitrifier method, Rapid Commun. Mass Spectrom., 23, 3753-3762, https://doi.org/10.1002/rcm.4307, 2009.

Granger, J., Sigman, D. M., Rohde, M., Maldonado, M., and Tortell, P.: N and O isotope effects during nitrate assimilation by unicellular prokaryotic and eukaryotic plankton cultures, Geochim. Cosmochim. Acta, 74, 1030 -1040, https://doi.org/10.1016/j.gca.2009.10.044, 2010.

560 Grasshoff, K., Kremling, K., and Ehrhardt, M.: Methods of seawater analysis, John Wiley \& Sons, 2009.

Gu, B., Ju, X., Chang, J., Ge, Y., and Vitousek, P. M.: Integrated reactive nitrogen budgets and future trends in China, Proc. Natl. Acad. Sci. USA, 112, 8792, https://doi.org/10.1073/pnas.1510211112, 2015.

IFA: Short-Term Fertilizer Outlook 2019 - 2020, Versailles, 8, 2019.

Kang, D.-J., Chung, C. S., Kim, S. H., Hong, G. H., and Kim, K.-R.: Oxygen isotope characteristics of seawaters in the

Yellow Sea, La mer, 32, 279-284, 1994.

Kérouel, R., and Aminot, A.: Fluorometric determination of ammonia in sea and estuarine waters by direct segmented flow analysis, Mar. Chem., 57, 265-275, https://doi.org/10.1016/S0304-4203(97)00040-6, 1997.

Kim, H., Park, G.-H., Lee, S.-E., Kim, Y.-i., Lee, K., Kim, Y.-H., and Kim, T.-W.: Stable isotope ratio of atmospheric and seawater nitrate in the East Sea in the northwestern Pacific ocean, Mar. Pollut. Bull., 149, 110610,

570 https://doi.org/10.1016/j.marpolbul.2019.110610, 2019.

Lehmann, M. F., Sigman, D. M., and Berelson, W. M.: Coupling the $15 \mathrm{~N} / 14 \mathrm{~N}$ and 18O/160 of nitrate as a constraint on benthic nitrogen cycling, Mar. Chem., 88, 1-20, https://doi.org/10.1016/j.marchem.2004.02.001, 2004.

$\mathrm{Li}, \mathrm{Y}$. , Wolanski, E., and Zhang, H.: What processes control the net currents through shallow straits? A review with application to the Bohai Strait, China, Estuar. Coast. Shelf Sci., 158, 1-11, https://doi.org/10.1016/j.ecss.2015.03.013, 5752015.

Li, Z., Walters, W. W., Hastings, M. G., Zhang, Y., Song, L., Liu, D., Zhang, W., Pan, Y., Fu, P., and Fang, Y.: Nitrate Isotopic Composition in Precipitation at a Chinese Megacity: Seasonal Variations, Atmospheric Processes, and Implications for Sources, Earth and Space Sci., https://doi.org/10.1029/2019EA000759, 2019.

Liu, S., Hong, G.-H., Zhang, J., Ye, X., and Jiang, X.: Nutrient budgets for large Chinese estuaries, Biogeosciences, 6 , 580 2245-2263, https://doi.org/10.5194/bg-6-2245-2009, 2009.

Liu, S. M., Zhang, J., and Jiang, W. S.: Pore water nutrient regeneration in shallow coastal Bohai Sea, China, J. Oceanogr., 59, 377-385, https://doi.org/10.1023/A:1025576212927, 2003.

Liu, S. M., Li, L. W., and Zhang, Z.: Inventory of nutrients in the Bohai, Cont. Shelf Res., 31, 1790 -1797, https://doi.org/10.1016/j.csr.2011.08.004, 2011.

585 Liu, S. M., Altabet, M. A., Zhao, L., Larkum, J., Song, G. D., Zhang, G. L., Jin, H., and Han, L. J.: Tracing Nitrogen Biogeochemistry During the Beginning of a Spring Phytoplankton Bloom in the Yellow Sea Using Coupled Nitrate Nitrogen and Oxygen Isotope Ratios, J. Geophys. Res.-Biogeo., 122, 2490-2508, 10.1002/2016jg003752, 2017. 
https://doi.org/10.5194/bg-2020-471

Preprint. Discussion started: 21 December 2020

(c) Author(s) 2020. CC BY 4.0 License.

(c) (i)

Liu, S. M., Ning, X., Dong, S., Song, G., Wang, L., Altabet, M. A., Zhu, Z., Wu, Y., Ren, J. L., and Liu, C. G.: Source Versus Recycling Influences on the Isotopic Composition of Nitrate and Nitrite in the East China Sea, J. Geophys. Res. -

Oeans, 125, e2020JC016061, https://doi.org/10.1029/2020JC016061, 2020.

Lu, C. C., and Tian, H.: Global nitrogen and phosphorus fertilizer use for agriculture production in the past half century: shifted hot spots and nutrient imbalance, Earth System Science Data, 9, 181, 10.5194/essd-9-181-2017, 2017.

Luo, X., and Jiao, J. J.: Submarine groundwater discharge and nutrient loadings in Tolo Harbor, Hong Kong using multiple geotracer-based models, and their implications of red tide outbreaks, Water Res., 102, 11-31, https://doi.org/10.1016/j.watres.2016.06.017, 2016.

Ma, S., Xin, F., Cui, Y., and Qiao, X.: Assessment of Main Pollution Matter Volume into the Sea from Yellow River and Xiaoqing Rive, Progress in Fishery Sciences (in Chinese), 25, 47-51, 2004.

Möbius, J.: Isotope fractionation during nitrogen remineralization (ammonification): Implications for nitrogen isotope biogeochemistry, Geochim. Cosmochim. Acta, 105, 422-432, https://doi.org/10.1016/j.gca.2012.11.048, 2013.

Montoya, J. P., Carpenter, E. J., and Capone, D. G.: Nitrogen fixation and nitrogen isotope abundances in zooplankton of the oligotrophic North Atlantic, Limnol. Oceanogr., 47, 1617-1628, https://doi.org/10.4319/lo.2002.47.6.1617, 2002.

Müller Schmied, H., Eisner, S., Franz, D., Wattenbach, M., Portmann, F. T., Flörke, M., and Döll, P.: Sensitivity of simulated global-scale freshwater fluxes and storages to input data, hydrological model structure, human water use and calibration, Hydrology and Earth System Sciences, 18, 3511-3538, 10.5194/hess-18-3511-2014, 2014.

Murphy, J., and Riley, J. P.: A modified single solution method for the determination of phosphate in natural waters, Anal. Chim. Acta, 27, 31-36, 1962.

MWR, C.: China River Sediment Bulletin 2018 (in Chinese), Beijing, 81, 2019.

Ning, X., Lin, C., Su, J., Liu, C., Hao, Q., Le, F., and Tang, Q.: Long-term environmental changes and the responses of the ecosystems in the Bohai Sea during 1960-1996, Deep Sea Research Part II: Topical Studies in Oceanography, 57, 1079-1091, https://doi.org/10.1016/j.dsr2.2010.02.010, 2010.

Pätsch, J., Serna, A., Dähnke, K., Schlarbaum, T., Johannsen, A., and Emeis, K.-C.: Nitrogen cycling in the German Bight (SE North Sea)—Clues from modelling stable nitrogen isotopes, Cont. Shelf Res., 30, 203 -213,

$615 \quad$ https://doi.org/10.1016/j.csr.2009.11.003, 2010.

Peterson, R. N., Burnett, W. C., Taniguchi, M., Chen, J., Santos, I. R., and Ishitobi, T.: Radon and radium isotope assessment of submarine groundwater discharge in the Yellow River delta, China, J. Geophys. Res. -Oeans, 113, https://doi.org/10.1029/2008JC004776, 2008.

Serna, A., Pätsch, J., Dähnke, K., Wiesner, M. G., Hass, H. C., Zeiler, M., Hebbeln, D., and Emeis, K. - C.: History of anthropogenic nitrogen input to the German Bight/SE North Sea as reflected by nitrogen isotopes in surface sediments, sediment cores and hindcast models, Cont. Shelf Res., 30, 1626-1638,

https://doi.org/10.1016/j.csr.2010.06.010, 2010. 
https://doi.org/10.5194/bg-2020-471

Preprint. Discussion started: 21 December 2020

(c) Author(s) 2020. CC BY 4.0 License.

Sigman, D. M., Casciotti, K. L., Andreani, M., Barford, C., Galanter, M., and Böhlke, J.: A bacterial method for the nitrogen isotopic analysis of nitrate in seawater and freshwater, Anal. Chem., 73, 4145-4153,

https://doi.org/10.1021/ac010088e, 2001.

Sigman, D. M., Granger, J., DiFiore, P. J., Lehmann, M. M., Ho, R., Cane, G., and van Geen, A.: Coupled nitrogen and oxygen isotope measurements of nitrate along the eastern North Pacific margin, Global Biogeochem. Cycles, 19, https://doi.org/10.1029/2005GB002458, 2005.

Sigman, D. M., DiFiore, P. J., Hain, M. P., Deutsch, C., Wang, Y., Karl, D. M., Knapp, A. N., Lehmann, M. F., and Pantoja, S.: The dual isotopes of deep nitrate as a constraint on the cycle and budget of oceanic fixed nitrogen, Deep-Sea Res. Pt. I, 56, 1419-1439, https://doi.org/10.1016/j.dsr.2009.04.007, 2009.

Sigman, D. M., and Fripiat, F.: Nitrogen Isotopes in the Ocean, in: Encyclopedia of Ocean Sciences (Third Edition), edited by: Cochran, J. K., Bokuniewicz, H. J., and Yager, P. L., Academic Press, Oxford, 263-278, 2019.

Smith, S. V., Swaney, D. P., Talaue-Mcmanus, L., Bartley, J. D., Sandhei, P. T., McLAUGHLIN, C. J., Dupra, V. C.,

Crossland, C. J., Buddemeier, R. W., and Maxwell, B. A.: Humans, hydrology, and the distribution of inorganic nutrient loading to the ocean, Bioscience, 53, 235-245, https://doi.org/10.1641/0006-3568(2003)053[0235:HHATDO]2.0.CO;2, 2003.

Soares, M.: Biological denitrification of groundwater, Water, Air, Soil Pollut., 123, $183-193,2000$.

Song, W., Liu, X.-Y., Wang, Y.-L., Tong, Y.-D., Bai, Z.-P., and Liu, C.-Q.: Nitrogen isotope differences between atmospheric nitrate and corresponding nitrogen oxides: A new constraint using oxygen isotopes, Sci. Total Environ., 701, 134515, https://doi.org/10.1016/j.scitotenv.2019.134515, 2020.

Su, J.: A review of circulation dynamics of the coastal oceans near China (in Chinese), Acta Oceanol. Sin., 23, 1 -16, 2001.

Sugimoto, R., Kasai, A., Miyajima, T., and Fujita, K.: Transport of oceanic nitrate from the continental shelf to the coastal basin in relation to the path of the Kuroshio, Cont. Shelf Res., 29, 1678-1688, https://doi.org/10.1016/j.csr.2009.05.013, 2009.

Umezawa, Y., Yamaguchi, A., Ishizaka, J., Hasegawa, T., Yoshimizu, C., Tayasu, I., Yoshimura, H., Morii, Y., Aoshima, T., and Yamawaki, N.: Seasonal shifts in the contributions of the Changjiang River and the Kuroshio Current to nitrate dynamics at the continental shelf of the northern East China Sea based on a nitrate dual isotopic composition approach, Biogeosci. Disc., 10, 10143-10188, https://doi.org/10.5194/bg-11-1297-2014, 2013.

Wang, J., Yu, Z., Wei, Q., and Yao, Q.: Long-term nutrient variations in the Bohai Sea over the past 40 years, J. Geophys. Res.-Oeans, 124, 703-722, https://doi.org/10.1029/2018JC014765, 2019.

Wang, W., Yu, Z., Song, X., Wu, Z., Yuan, Y., Zhou, P., and Cao, X.: The effect of Kuroshio Current on nitrate dynamics in the southern East China Sea revealed by nitrate isotopic composition, J. Geophys. Res. -Oeans, 121, 7073-7087, 
https://doi.org/10.5194/bg-2020-471

Preprint. Discussion started: 21 December 2020

(c) Author(s) 2020. CC BY 4.0 License.

(c) (1)

Wang, W., Yu, Z., Song, X., Wu, Z., Yuan, Y., Zhou, P., and Cao, X.: Characteristics of the $\$ \$ \backslash$ delta $\wedge\{15\} N_{-}\left\{N N_{-} 3\right\}$ $\$ \$ \delta 15 N N O 3 d i s t r i b u t i o n$ and its drivers in the Changjiang River estuary and adjacent waters, Chin. J. Oceanol. Limnol., 35, 367-382, 10.1007/s00343-016-5276-x, 2017.

Wang, X., Li, H., Jiao, J. J., Barry, D. A., Li, L., Luo, X., Wang, C., Wan, L., Wang, X., and Jiang, X.: Submarine fresh groundwater discharge into Laizhou Bay comparable to the Yellow River flux, Sci. Rep.-UK, 5, 8814, https://doi.org/10.1038/srep08814, 2015.

Wankel, S. D., Kendall, C., Francis, C. A., and Paytan, A.: Nitrogen sources and cycling in the San Francisco Bay Estuary: A nitrate dual isotopic composition approach, Limnol. Oceanogr., 51, 1654-1664,

https://doi.org/10.4319/lo.2006.51.4.1654, 2006.

665 Wankel, S. D., Kendall, C., Pennington, J. T., Chavez, F. P., and Paytan, A.: Nitrification in the euphotic zone as evidenced by nitrate dual isotopic composition: Observations from Monterey Bay, California, Global Biogeochem. Cycles, 21, https://doi.org/10.1029/2006GB002723, 2007.

Wong, G. T.: Removal of nitrite interference in the Winkler determination of dissolved oxygen in seawater, Mar. Chem., 130, 28-32, https://doi.org/10.1016/j.marchem.2011.11.003, 2012.

670 Wu, S.: Oxygen isotope compositions of seawaters in the Huanghai (Yellow) Sea and the Bohai Sea, Science in China, Ser. B, 8, 1991.

Wu, Z., Yu, Z., Song, X., Wang, W., Zhou, P., Cao, X., and Yuan, Y.: Key nitrogen biogeochemical processes in the South Yellow Sea revealed by dual stable isotopes of nitrate, Estuar. Coast. Shelf Sci., 225, 106222, https://doi.org/10.1016/j.ecss.2019.05.004, 2019.

675 Wurl, O.: Practical guidelines for the analysis of seawater, CRC press, 2009.

Xu, S., Song, J., Li, X., Yuan, H., Li, N., Duan, L., and Sun, P.: Changes in nitrogen and phosphorus and their effects on phytoplankton in the Bohai Sea, Chin. J. Oceanol. Limnol., 28, 945-952, 10.1007/s00343-010-0005-3, 2010.

Yang, Z., Chen, J., Li, H., Jin, H., Gao, S., Ji, Z., Zhu, Y., Ran, L., Zhang, J., and Liao, Y.: Sources of nitrate in Xiangshan Bay (China), as identified using nitrogen and oxygen isotopes, Estuar. Coast. Shelf Sci., 207, 109-118,

$680 \quad$ https://doi.org/10.1016/j.ecss.2018.02.019, 2018.

Yellow River Conservancy Commission of MWR, C.: Yellow River Sediment Bulletin 2018 (in Chinese), Yellow River Conservancy Commission of MWR, China, Zhengzhou, 35, 2019.

Yu, H., Yu, Z., Song, X., Cao, X., Yuan, Y., and Lu, G.: Seasonal variations in the nitrogen isotopic composition of dissolved nitrate in the Changjiang River estuary, China, Estuar. Coast. Shelf Sci., 155, 148 -155,

685 https://doi.org/10.1016/j.ecss.2015.01.017, 2015.

Yu, Q., Lou, A., Zhang, X., and Li, N.: Numerical Analysis on the Impact of Main River Runoff on the Plain Distribution in the Low-Salinity Area at North Liaodong Bay, Transactions of Oceanology and Limnology (in CHinese), 88-96, 2018. 
https://doi.org/10.5194/bg-2020-471

Preprint. Discussion started: 21 December 2020

(c) Author(s) 2020. CC BY 4.0 License.

(c) (1)

Zhang, G., Zhang, J., and Liu, S.: Characterization of nutrients in the atmospheric wet and dry deposition observed at the two monitoring sites over Yellow Sea and East China Sea, Journal of Atmospheric Chemistry, 57, 41-57, 10.1007/s10874-007-9060-3, 2007.

Zhang, J., Yu, Z., Raabe, T., Liu, S., Starke, A., Zou, L., Gao, H., and Brockmann, U.: Dynamics of inorganic nutrient species in the Bohai seawaters, J. Mar. Syst., 44, 189-212, https://doi.org/10.1016/j.jmarsys.2003.09.010, 2004. Zhang, L., Song, L., Zhang, L., Shao, H., Chen, X., and Yan, K.: Seasonal dynamics in nitrous oxide emissions under different types of vegetation in saline-alkaline soils of the Yellow River Delta, China and implications for ecorestoring coastal wetland, Ecol. Eng., 61, 82-89, https://doi.org/10.1016/j.ecoleng.2013.09.065, 2013.

Zhang, Y., Liu, X., Fangmeier, A., Goulding, K., and Zhang, F.: Nitrogen inputs and isotopes in precipitation in the North China Plain, Atmos. Environ., 42, 1436-1448, https://doi.org/10.1016/j.atmosenv.2007.11.002, 2008. Zhang, Y., Li, H., Wang, X., Zheng, C., Wang, C., Xiao, K., Wan, L., Wang, X., Jiang, X., and Guo, H.: Estimation of submarine groundwater discharge and associated nutrient fluxes in eastern Laizhou Bay, China using 222Rn, Journal of Hydrology, 533, 103-113, https://doi.org/10.1016/j.jhydrol.2015.11.027, 2016.

Zhang, Z., Zheng, N., Zhang, D., Xiao, H., Cao, Y., and Xiao, H.: Rayleigh based concept to track NOx emission sources in urban areas of China, Sci. Total Environ., 135362, https://doi.org/10.1016/j.scitotenv.2019.135362, 2019.

Zhao, L., Wei, H., and Feng, S.: Annual Cycle and Budgets of Nutrients in the bohai Sea, 2002.

705 Zhao, Y., Zhang, L., Chen, Y., Liu, X., Xu, W., Pan, Y., and Duan, L.: Atmospheric nitrogen deposition to China: A model analysis on nitrogen budget and critical load exceedance, Atmos. Environ., 153, 32 -40, https://doi.org/10.1016/j.atmosenv.2017.01.018, 2017.

Zong, Z., Wang, X., Tian, C., Chen, Y., Fang, Y., Zhang, F., Li, C., Sun, J., Li, J., Zhang, G. J. E. S., and technology: First assessment of $\mathrm{NO} \times$ sources at a regional background site in North China using isotopic analysis linked with modeling, 51, 5923-5931, 2017. 